University of Louisville

ThinkIR: The University of Louisville's Institutional Repository

Electronic Theses and Dissertations

$5-2018$

\title{
"Triggers": systematic and social cues for black college student racial self-consciousness and rejection sensitivity, race-based.
}

LeAnna T. Luney

University of Louisville

Follow this and additional works at: https://ir.library.louisville.edu/etd

Part of the Adult and Continuing Education Commons, African American Studies Commons, Cognition and Perception Commons, Curriculum and Social Inquiry Commons, Ethnic Studies Commons, Multicultural Psychology Commons, School Psychology Commons, and the Social Psychology Commons

\section{Recommended Citation}

Luney, LeAnna T., "'Triggers": systematic and social cues for black college student racial selfconsciousness and rejection sensitivity, race-based." (2018). Electronic Theses and Dissertations. Paper 2909.

https://doi.org/10.18297/etd/2909

This Master's Thesis is brought to you for free and open access by ThinkIR: The University of Louisville's Institutional Repository. It has been accepted for inclusion in Electronic Theses and Dissertations by an authorized administrator of ThinkIR: The University of Louisville's Institutional Repository. This title appears here courtesy of the author, who has retained all other copyrights. For more information, please contact thinkir@louisville.edu. 


\title{
“TRIGGERS": SYSTEMATIC AND SOCIAL CUES FOR BLACK COLLEGE STUDENT RACIAL SELF-CONCIOUSNESS AND REJECTION SENSITIVITY, RACE BASED
}

\author{
By \\ LeAnna T. Luney \\ B.A., Berea College, 2016
}

A Thesis Submitted to the Faculty of the College of Arts and Sciences of the University of Louisville in Partial Fulfillment of the Requirements for the Degree of

\author{
Master of Arts \\ in \\ Pan African Studies \\ Department of Pan-African Studies \\ Louisville, Kentucky
}

May 2018 



\section{"TRIGGERS": SYSTEMATIC AND SOCIAL CUES FOR BLACK COLLEGE STUDENT RACIAL SELF-CONCIOUSNESS AND REJECTION SENSITIVITY, RACE BASED}

By

LeAnna T. Luney

B.A. Berea College, 2016

May 8, 2018

by the following Thesis Committee:

Dr. W. Carson Byrd

Dr. Latrica E. Best

Dr. Derrick Brooms 


\begin{abstract}
“TRIGGERS": SYSTEMATIC AND SOCIAL CUES FOR BLACK COLLEGE STUDENT RACIAL SELF-CONCIOUSNESS AND REJECTION SENSITIVITY,
\end{abstract} RACE BASED

LeAnna T. Luney

May 8, 2018

Scholars have examined black student well-being in varying ways including through the framing of race-based rejection sensitivity (Downey \& Feldman, 1996; Mendoza-Denton, Downey, Purdie, Davis, \& Pietrzak, 2002) and racial selfconsciousness (Clark \& Clark, 1939). Research shows that black students perform worse academically when they display high levels of race-based rejection sensitivity and racial self-conscious levels (Brannon \& Taylor, 2015; Clark \& Clark, 1939; Koehler \& Skvoretz, 2010), and feelings of racial self-consciousness or rejection sensitivity stem from discriminatory and prejudicial experiences. However, research has not fully connected the broader context surrounding black students in college to their high levels of anxiousness and their academic performance. The current study addresses how the college environment can influence black students' racial self-conscious levels by examining four campus climate-related processes of race-based rejection sensitivity: perceptions of racial discrimination, perceptions of institutional commitments to racial diversity, perceptions of racial separation on campus, and perceptions of black student 
visibility. Additionally, this study considers how colorism may influence race-based rejection sensitivity and racial self-consciousness among black students, and how students' worldview in relation to other blacks may shape their college experiences. Through analyses of data collected as part of the National Longitudinal Survey of Freshmen, the current study utilizes ordinary least squares regression, means comparison, and binomial logistic regression analyses to identify how the aforementioned factors trigger black students' racial self-conscious levels during college.

KEYWORDS: Black students; Social Psychology; Student Perceptions; Structural Inequality; Campus Climate. 


\section{TABLE OF CONTENTS}

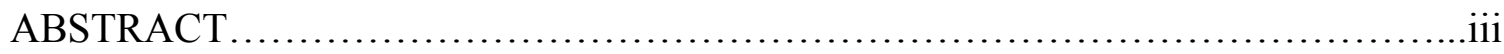

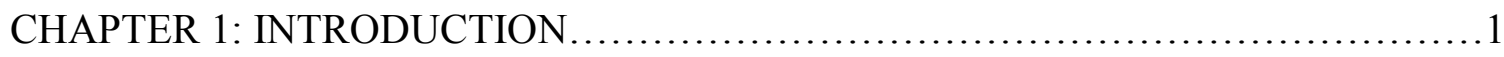

1.1. Research Questions

1. 2. Thesis Overview

CHAPTER 2: LITERATURE REVIEW $\ldots \ldots \ldots \ldots \ldots \ldots \ldots \ldots \ldots \ldots \ldots \ldots \ldots \ldots \ldots$

2.1. Racial Self-Consciousness

2.2. Rejection Sensitivity

2.3. Campus Climates and Rejection Sensitivity Processes

2.4. Other Factors Influencing Racial Self-Consciousness

2.5. Hypotheses

CHAPTER 3: METHODOLOGICAL APPROACH..................................27

3.1. Dataset

3.2. Materials

3.3. Statistical Analyses 
CHAPTER 4: FACTORS TRIGGERING RACE-BASED REJECTION

SENSITIVTY AND RACIAL SELF-CONSCIOUS AMONG BLACK

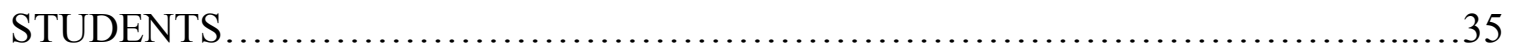

CHAPTER 5: THE TIPPING POINT: EXAMINING BLACK STUDENTS

WITH HIGH RACIAL SELF CONSCIOUSNESS

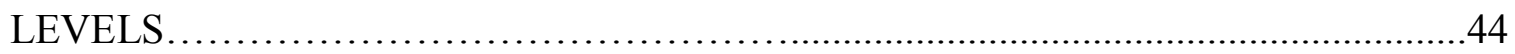

CHAPTER 6: CONCLUSION AND IMPLICATIONS..............................51

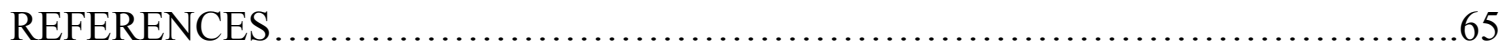

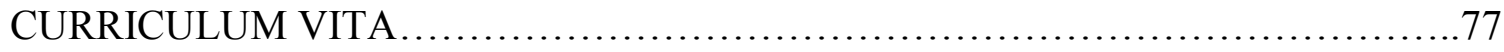




\section{CHAPTER 1: INTRODUCTION}

Maya is a 20 year old black woman attending Red Tree College, a liberal arts institution too far away from her home in Chicago, IL. In spite of being so far away from home, Maya has found ways to be involved at her college. She is a member of her school's black student union, campus activities board, and has a work-study position in Red Tree College's admissions office as a welcome center tour guide.

During Maya's staff meeting at admissions, the vice president of admissions began a conversation about incoming students for the upcoming fall. "For recruitment this year, we will be focusing on a different demographic than in the past. After observing the numbers, we are still able to reach our commitment to diversity by admitting more female and low-income students. Please recruit from these backgrounds, as new administrative policies are funding these communities of students."

In this instance, Maya read between the lines. She thought of race. Not any race, but of her own. Although the vice president of admissions stated that admissions recruiters should still strive for diversity, Maya knew that this meant Red Tree College's commitment to racial diversity was no longer a priority. 
Maya is representative of hundreds of black college students attending US colleges and universities. Their experiences oftentimes consist of racial awakenings, or instances where they are reminded that they are black in a predominantly white space, which is also known as racial self-consciousness. However, black students' racial selfconsciousness is not an isolated or spontaneous event. There are several factors that contribute to one's racial self-consciousness, and many of these are found within the campus climate at higher education institutions.

Racial self-consciousness refers to race becoming salient to an individual, in an environment, due to current or past experiences in similar settings (Clark \& Clark,1939). Often researchers examine racial self-consciousness (RSC) when observing black students' experiences in higher education because of racism on campus. In some cases, black college students experience racial self-consciousness as a result of discrimination, stereotypes, microaggressions, and closeness to other blacks. These experiences result in race-based rejection sensitivity (RS-race) and may also cause racial self-consciousness, since both concepts are heavily associated with racially triggering events. Because both RS-race and RSC emphasize black students' vigilance based on current and past experiences, the two variables are considered in relation to one another in this thesis. Though RSC is the main variable of interest in the current study, it remains a loose concept with little research uncovering what factors can influence it among black college students (Brannon, Markus, \& Taylor, 2015; Clark \& Clark, 1939; Koehler \& Skovoretz, 2010). However, a theoretical perspective could complement this research area and provide insight into how RSC may change among black students during college. More specifically, studies of race-based rejection sensitivity relate to how students' RSC levels 
may change due to their perceptions and experiences of discrimination on college campuses. Thus, research on RS-race (see Downey \& Feldman, 1996; Mendoza-Denton, Goldman-Flythe, Pietrzak, Downey, Aceves, 2010; Page-Gould, Mendoza-Denton, \& Mendes, 2014; Wu, Lyons, \& Leong, 2015) can assist with explaining how aspects of an institution's campus climate can influence different psychological processes among black students.

Rejection sensitivity occurs when individuals may expect to be rejected by others, based on their personality (Downey \& Feldman, 1996). Furthermore, one may experience rejection sensitivity based on status which may include race, gender, disability, or sexuality. Thus, the current study emphasizes racial status, or race-based rejection sensitivity (RS-race). In the context of race and higher education, RS-race is described as black students displaying hesitance toward an institution, faculty, staff, and other students (Lett \& Wright, 2003; Smith \& Hopkins, 2004; Boyraz, et al., 2013; Henson, et al., 2013; Mendoza-Denton, et al., 2008). Findings show that black students at historically white colleges and universities display lower academic and social performance when experiencing high levels of rejection sensitivity (Lett \& Wright, 2003; Smith \& Hopkins, 2004; Boyraz, et al., 2013; Henson, et al., 2013; Mendoza-Denton, et al., 2008). In line with previous research on rejection sensitivity (Mendoza-Denton et al., 2002), the purpose of the current study is to discover how systemic factors associated with the campus climates of colleges and universities impact four interrelated RS-race processes among black students, and how these four processes trigger students' RSC levels.

The literature suggests that RSC among black students may be shaped by heightened levels of RS-race resulting from and the anticipation of discriminatory 
experiences college campuses (Brannon \& Taylor, 2015; Koehler Skvoretz, 2010).

However, scholars have not fully considered the relationship between racial selfconscious and race-based rejection sensitivity. Although researchers have not clearly distinguished the relationship between structural issues associated with institutional racism (Carmichael \& Hamilton 1967) and their psychological effects on black students, my study aims to draw this connection by focusing on rejection sensitivity processes that can influence black students' racial self-conscious. The specific college-related processes include how students perceive their presence on campus (i.e., visibility), the institutional commitment to diversity, possible racial and ethnic divides among students, and perceptions of and experiences with racial discrimination during college. My research project contributes important insights to the literature on black students' experiences in higher education. I analyze how black students' racial self-consciousness, using rejection sensitivity research as a theoretical framework, changes depending on their experiences and perceptions of racial discrimination, their institution's commitments to racial diversity, racial separation, and black student visibility on campus. I also consider how colorism, and closeness to the black community can also influence both RS-race and RSC levels among black students. Similar to previous research examining the well-being of black college students (Clark \& Clark, 1939; Downey \& Feldman, 1996; MendozaDenton, Downey, Purdie, Davis, \& Pietrzak, 2002), my research highlights black students' vigilance under the scope of structural and social issues in higher education that can impede their academic success. 


\subsection{Research Questions}

The overarching research question is can campus climate affect black students' perceptions of their race? The following section addresses the overarching focus of the study; it examines structural and social concepts that black students face while attending college, how black students psychologically process these concepts, and how they may play out behaviorally.

As noted above, students' racial discrimination experiences, and perceptions of institutional commitments to diversity, black student visibility, and racial separation on campus serve as four proximate measures for RS-race processes associated with the campus climate. Previous studies suggest that discrimination experiences (Wu, Lyons, \& Leong, 2015) and perceptions of policies to address racial discrimination and inequality on campus (Brannon \& Taylor, 2015; Henson, Derlega, \& Pearson, 2013; MendozaDenton, Downey, Purdie, Davis, \& Piertzak, 2002) can influence RS-race levels among black students, which then could trigger their RSC levels. However, although other studies suggest additional aspects of campus experiences can influence students RS-race and RSC levels (Jackson, Sweeney, \& Welcher, 2014; Karkouti, 2016; Koehler, \& Skvoretz, 2010), little research exists on how students' perceptions of racial separation and black students' visibility can influence these levels. Therefore, I ask: how do racial discrimination experiences and perceptions of policies that address such discrimination influence black students RS-race and RSC levels when considering a more holistic view of how the campus climate influences students' experiences?

Lastly, two other aspects of students' lives may influence their college experiences. Colorism (Bonilla-Silva, 2015; Hunter, 2015; Monk, 2014; Monk, 2015; 
Okonofua \& Eberhardt, 2015), or the discriminatory treatment of people based on physiological features and sometimes referred to as a "pigmentocracy" (Bonilla-Silva 2017), may influence black students' rejection sensitivity and self-consciousness levels. No previous study known to the author has examined how colorism may influence RSrace and RSC levels associated with black students' college experiences. Given this possibility, I ask: how does colorism shape students RS-race and RSC levels on college campuses? Additionally, studies indicate that black students' stronger connections to their communities through cultural pride increases students' vigilance in higher education institutions (Telesford, Mendoza-Denton, \& Worrell, 2013; Page-Gould, MendozaDenton, \& Mendes, 2014). Despite these findings, more information is needed to understand how black students' connections to other black communities may influence their rejection sensitivity and self-consciousness levels. Thus, I ask: how does black students' closeness toward other black community members influence their RS-race and RSC levels during college?

\subsection{Thesis Overview}

In the current thesis, I discuss RSC and RS-race systematic and social cues for black students at US colleges and universities. Chapter 2 presents the literature review guiding the current study. I highlight research on both racial self-consciousness and racebased rejection sensitivity and how this research relates to black college student experiences. My coverage of relevant literature concludes with a summation of research elaborating on the black college students facing discrimination, particularly as they relate to institutional commitments to racial diversity, perceptions of racial separation and black student visibility on campus, and other social psychological processes reflecting students' 
connections to black communities and experiences with colorism while pursuing their college degrees.

Chapter 3 presents the methods and statistical analyses utilized in this thesis. The dataset, different variables, and analytical approach I used for the purposes of the current study are described in detail. The dataset consists of 796 black student respondents from the National Longitudinal Study of Freshmen (NLSF). Each measure included in the analyses are described in detail.

I statistically report the results in Chapter 4. Seven variables have significant relationships with racial self-consciousness. Noteworthy models in this study concern how skin color, region, and college type determine black students' experiences on campus, perceptions of racial separation on campus, and black student visibility. Other highlighted models are how campus climate variables (i.e. racial discrimination on campus, racial separation, and black student visibility) affect black students' racial selfconsciousness. Some background variables also affected black college students' racial self-consciousness.

In Chapter 5 I explain which variables are most salient for students with high levels of RSC/RS-race. Similar to predictors in chapter four, experiences with racial discrimination, racial separation on campus, and black student visibility are significant predictors for black students with high levels of racial self-consciousness. When inserted into models, no background characteristics significantly predicted high levels of racial self-consciousness. 
Chapter 6 is the conclusion and implications section, where I compare the models to previous research. I examine the models through theoretical viewpoints from several fields including black psychology, Western psychology, and education. I also discuss the models in their day-to-day application, particularly regarding the role of black students' background characteristics, their mental health, and using their perceptions to improve campus climate. The thesis concludes with suggestions on how scholars and university policymakers should address RSC and RS-race in future studies and on campus. 


\section{CHAPTER 2: LITERATURE REVIEW}

In order to connect how black college students' racial self-consciousness (RSC) is influenced by different race-based rejection sensitivity (RS-race) processes, I explore how these processes reflect the campus climates and colleges and universities. I elaborate on the pertinent literatures of racial self-consciousness, rejection sensitivity, racial discrimination on campus, institutional commitments to racial diversity, racial separation, and black student visibility on campus. Despite the large amount of research on these aspects of black students' lives, rarely have researchers connected RSC and RSrace together, let alone through using the campus climate as a framework for understanding such connections.

\subsection{Racial Self-Consciousness}

Racial self-consciousness (RSC) is the main outcome of interest in the current study. Initial studies of RSC (sometimes referred to as race self-awareness) appeared in the early 1900s. In particular, Clark and Clark (1939) defined race consciousness as “...consciousness of self as belonging to a specific group which is differentiated from other groups by obvious physical characteristics" (Clark \& Clark, 1939, p. 594-595). Their study stressed that race consciousness is a major aspect of self-consciousness, and that black people do not have a sense of the latter without racial awareness. Out of 150 African American children, Clark and Clark (1939) found that black boys clearly identified themselves as black at three and four years old. On the other hand, white 
participants showed no racial identification at all ages. From their study, Clark and Clark (1939) show us that racial consciousness plays a crucial role in black students' educations and educational experiences, since racial consciousness is prevalent in African Americans' lives from a young age in Western countries with histories of colonization and enslavement. For the purposes of the current study, I use Clark and Clark's (1939) definition of RSC.

Scholars continue utilizing RSC as a conceptual perspective to carryout studies about African American students in higher education in more recent studies (Brannon \& Taylor, 2015; Koehler \& Skvoretz, 2010). For example, students are reminded of their race in college living spaces. Koehler and Skvoretz (2010) studied racial segregation in campus housing, and asked participants to capture their first-year college experiences with photos and provide descriptions of these photos. Racial consciousness on campus persisted as a prevalent theme in the study. Students stressed several factors that heightened their RSC such as white students' reactions toward them on a predominantly white campus. These reactions included constant stares, racial comments, prejudices, and microaggressions explained as racial "ignorance." The lack of support services for black students on campus and other services in the college town also heightened respondents' RSC, which also related to a small African American population in the college town. Koehler and Skvoretz's (2010) study addresses a small segment of the situations black students face when navigating the white spaces of college campuses that can trigger RSC.

Researchers have also explored black students' RSC in relation to their academic performance. Brannon and Taylor (2015) found African American students forgo two different forms of double consciousness on a college campus. When they identified with 
American culture, black students displayed independent self-schemas. Additionally, when African American students identified with black culture, academic fit and academic identification increased. Therefore, black students had better academic performance when they identified with black culture (Brannon \& Taylor, 2015). Importantly, students who recognize their race through culture are stronger academic performers. Typically, black student RSC can include negative feelings, performance, or behavior because students are becoming cognizant of their race through adverse interactions on campus. Yet, in Brannon and Taylor's (2015) study, black student RSC is beneficial in African American students' lives, academically. Although it is the main dependent variable in the current study, RSC is understudied in relation to black college students' experiences and more research is needed to uncover what factors can lead to increased RSC levels through adverse experiences in college. A more thoroughly studied phenomenon is rejection sensitivity, which links black students' experiences with their behaviors and other psychological processes. Thus, this research could extend how RSC changes during college for black students.

\subsection{Rejection Sensitivity}

Rejection sensitivity (Downey \& Feldman, 1996) occurs when one expects to be rejected by others based on components of their personality. Many studies addressing rejection sensitivity occurred in the 1970s and 1980s, with emphases on personality and social interaction. For example, scholars (Mehrabian, 1970a; Mehrabian, 1970b; Mehrabian \& Ksionzky, 1972) observed how participants - often college students reacted before interacting with others and how the individual expected to be rejected, especially depending on if the individual and others had similar ideas. Particularly, 
people with rejection sensitivity were more expectant of rejection from others if they had different ideologies. In his studies, Mehrabian (1970a; 1970b; 1972) framed rejection sensitivity as an explanation for social interaction and often referred to it as a personality characteristic. Rejection sensitivity was also framed as an individual characteristic in studies where researchers utilized the assertion inventory, which measures behavior, discomfort, and other factors people may display in certain scenarios based on their personality type (Gambrill \& Richey, 1975; McNamra \& Delamater, 1984). While this literature pioneered rejection sensitivity research, it later shifted to a more categorical topic of study in which rejection sensitivity is studied in groups of people.

Individuals may display rejection sensitivity based on status such as race, gender, disability, or sexuality. A branch of rejection sensitivity specifically related to one's race is rejection sensitivity, race based. In many cases, college students are participants in studies, just as they were in studies in the past. Differently, though, rejection sensitivity based on personality is problematic when observing black college students with rejection sensitivity, race-based because it is framed as a personality characteristic, similar to initial studies. Yet, it is the result of discriminatory experiences (Wu et al., 2015). Although RS-race studies shed light on black students' experiences of vigilance, several issues occur pertaining to methodology and execution. Firstly, researchers display RSrace as the effect showing causes of the phenomenon. Secondly, in the rare occasion researchers examine causes of RS-race, the individual is portrayed as the source of the issue, which can also be called a "race effect" (Zuberi \& Bonilla-Silva, 2008). Unfortunately, excluding discrimination and focusing on individuals as the source of his or hers rejection sensitivity perpetuates ideas of pathology within black students. 
Furthermore, placing an emphasis on rejection sensitivity at the individual level undercuts the power of structural racism and its pressures triggering increases in black students' RSC.

As stated before, Wu et al. (2015) found that the source of this phenomenon is racially discriminatory experiences and prejudicial stressors. While its cause is often negative racial interactions in one's past, an effect of RS-race is poor self-esteem, which could relate to RSC. Researchers found that students with low RS-race levels experience a change in self-esteem when positive feedback is given to them. On the other hand, students with high levels of RS-race show no change in their current self-esteem when given positive feedback (Mendoza-Denton, Goldman-Flythe, Pietrzak, Downey, \& Aceves, 2010). Essentially, students who expect rejection based on their race are less receptive to positive feedback than students who do not expect rejection. When students are less receptive to positive feedback, they are more likely to have lower self-esteem. Thus, according to Mendoza-Denton et al. (2010), students with high levels of RS-race are more likely to have lower self-esteems because of they do not to receive positive feedback. In relation to RSC, students with low RSC levels may show increased selfesteem with positive feedback, whereas students with high racial self-consciousness may not have a change in self-esteem.

Other studies have observed how black students' feelings toward their institutions are triggered by racism on campus, and how these circumstances affect black student academic performance. Hensen, Derlega, and Pearson (2013) found racism and low institutional identity among black students increased their RS-race levels. Thus, these experiences may also increase one's self-consciousness. Their study also notes the 
importance for ethnic identity as it lowered RS-race levels. If the same processes that determined RS-race determine RSC, increased experiences and perceptions of racism on college campuses may predict black students' RSC in college. Moreover, more positive feelings toward institutions and intent to stay in school would occur as a result.

Scholars first addressed rejection sensitivity based on personality (Downey and Feldman, 1996), and later applied the phenomenon to status-based factors such as race. Mendoza-Denton et al. (2002) theorized RS-race in their observations of African American students attending historically white colleges and universities (HWCUs). From this phenomenon, self-esteem (Mendoza-Denton, et al., 2010) and interracial relationships (Page-Gould et al., 2014) were added to the literature. While only one study has been conducted on relationships between RS-race and cultural pride (Telesford, et al., 2013), feelings toward institutions is heavily sited in the literature (Lett \& Wright, 2003; Smith \& Hopkins, 2004; Boyraz, et al., 2013; Henson, et al., 2013; Mendoza-Denton, et al., 2008). Thus, the current study aims to connect how RS-race processes link to the college environments of students through the campus climate. Furthermore, RS-race studies serve as a blueprint for factors that occur in the college environment and contribute to black students' experiences. If RS-race studies show a relationship between the campus environment and students' feelings toward race and their race-based experiences and perceptions, a logical extension of this work is to study how RS-race processes anchored within colleges' campus climates can influence students' RSC levels.

\subsection{Campus Climates and Rejection Sensitivity Processes}

I elaborate on four components of campus climates that arguably reflect RS-race processes impacting black students' RSC levels. These four components include 
perceptions and experiences of racial discrimination in college, institutional commitment to racial diversity, racial separation on campus, and black student visibility. Previous research has not explored the relationship between each of these four components of the campus climate as they relate to RS-race processes (Essenburg, \& Matchett, 2013; Harper \& Yeung, 2013; Jackson et al., 2014; Johnson et al., 2014; Karkouti, 2016; Koehler \& Skvoretz, 2010; Lett \& Wright, 2003; Smith \& Hopkins, 2004). Since RSC and RS-race are based on experiences in a racially discriminatory society, which includes colleges and universities, it is important to consider how campus climates can influence the psychological well-being of black students and there may be a connection between RSC and RS-race and the other seven variables.

The experiences and perceptions of racial discrimination on college campuses is arguably the most direct connection to RS-race processes that can trigger RSC levels among students. Previous RS-race studies often ask for students to reflect on hypothetical experiences when they may worry about being racially discriminated against (see Mendoza-Denton, et al., 2008, 2002; Page Gould, et al. 2014). Thus, the campus-based experiences and perceptions of discrimination provides a direct measure of how RS-race functions for black students pursuing their degrees.

Despite increasing racial and ethnic diversity in society and on college campuses (Pipert, Essenburg, \& Matchett, 2013), black college students face racial segregation and underrepresentation (Harper \& Yeung, 2013; Johnson, Wasserman, Yidirim, \& Yonai, 2014). Research suggests that if students perceive that their institutions are not working toward campus diversity, negative social interactions, such as racial separation and discrimination, arise (Harper \& Yeung, 2013). When racial separation and racial 
discrimination occur on campus, minority students' grades decrease, they feel alienated, and lose sense of belonging at their colleges and universities. College campuses without commitments to racial diversity also foster low numbers of interracial friendships and heightened racial separation. Lastly, Karkouti (2016) reported that administrators silence black students and are inconsiderate of black student perceptions at institutions without commitments to racial diversity.

Johnson et al. (2014) studied white and black freshmen at a predominantly white research institution to find potential stressors and the degree to which these stressors would influence academic persistence in college. Like Karkouti's (2016) findings, black students faced several race-based stressors on campus due to a lack of diversity. Researchers found that black students observed or experienced racism on campus; furthermore, their academic performance decreased when they encountered or perceived racism. Johnson et al. (2014) suggested some students perceive racism on campus less because they may have attended predominantly white high schools, which would better prepare them for navigating majority white spaces like the university. This study shows that black students' perceptions of racism on campus negatively impacts their academic performance.

Scholars have examined how one's cultural pride changes RS-race levels. Telesford et al. (2013) found that if African American students have more pride in their culture, they show higher levels of RS-race, or vigilance toward their university at historically white colleges and universities (see also Mendoza-Denton \& Page-Gould, 2008). While these findings give more information about the relationship between cultural pride and RS-race, scholars studying the relationship between cultural pride and 
trust fail to recognize confounding variables that may play a role in how RS-race manifests. For instance, as black students become more culturally competent, they learn that higher education institutions have historically marginalized black people and other people of color (Dancey, Edwards, \& Davis, 2018; Wilder, 2013). This fact alone may inhibit student trust in the institution and increase student RS-race simultaneously. So, attributing black students' RS-race to their cultural pride is a limiting assertion. We should instead situate RS-race in relation to structural issues, such as historic racial marginalization at US college campuses and universities, and view RS-race as a symptom of this structural racism. As Hensen, Derlega, and Pearson (2013) found, black students with stronger ethnic identities in college also had lower levels of RS-race. Therefore, the current study examines how black students' worldview in relation to the broader black community may somewhat encapsulate cultural pride while also making connections to the realities of racial discrimination on campus in society that can influence both RS-race and RSC levels.

Given these findings, there exists structural roots for RS-race that can alter black student experiences at higher education institutions, particularly their academic performance. Psychologically stressing environmental stimuli including stereotype-threat occurrences (Smith \& Hopkins, 2004; Steele, 1997), the presence or absence of mental illness (Boyraz, Horne, Owens, \& Armstrong, 2013), and administrators' acceptance of African American culture (Lett \& Wright, 2003) influence how well African American students perform academically (Johnson, Wasserman, Yildirim, \& Yonai, 2014). If students feel that administrators accept black culture, a level of trust is developed in the administrators, who are reflections of the institution (Lett \& Wright, 2003). The more 
students trust the institution, among other factors, the better they perform in the classroom. Thus, if African American students begin to trust the institution, academic performance is enhanced. This can be reflected in how students perceive their institutions' commitment to promoting racial diversity on campus.

Closely related to the institutional commitment to racial diversity is perceiving racial separation on campus, which occurs when students feel that people segregate and/or are segregated by race or ethnicity. Rather than view racial segregation as an individual choice, the current thesis considers this societal reality a systematic or institutional phenomenon.

Perceived racial separation on campus is one of the most prominent themes in Koehler and Skvoretz's (2010) study. Respondents often felt that students of different races only affiliated with others of the same race, and that these same-race interactions were voluntary. Students provided several reasons for racial separation on campus including people feeling more comfortable with same-race peers, as opposed to feeling less comfortable with peers of a different race. In some cases, students felt that other African American students were unwelcoming because of cliques built prior to arriving at the college. Yet, all students in the study felt that racial separation on campus limited their college experiences.

In a similar study, Jackson, Sweeney, and Welcher (2014) examined the degree to which students want interracial friendship, what students think about racial separation at a predominantly white institution, and why students think racial separation exists. Researchers found similar findings as Koehler and Skvoretz (2010) as students felt that people established same-race friendships, that there was a high degree of racial separation 
on college campuses, and that people felt more comfortable with others of the same race. Jackson et al. (2014) suggested that racial separation would elicit stereotypes, more racial hostility toward racial minorities on campus, and decreased academic performance for minority students.

Some may assume that increased racial diversity would improve racial separation on college campuses, and in turn reduce RS-race levels among students. Yet, students attending racially diverse institutions continue to only interact with those of the same race, possibly because the campus climate reflects more institutional racial issues. Furthermore, according to Byrd (2017), prejudice does not dwindle automatically with increased diversity and social interactions among students. Thus, RS-race levels can directly relate to how racial separation on campus is multifaceted and not solely reflects where different groups are on campus or who they interact with, but can be a social psychological phenomenon that impacts how black students relate to their campuses and their connections to race.

Lastly, student visibility on campus can impact black students' RS-race and RSC levels. Visibility can literally refer to students' perceptions of their group's representation on campus but may also connect to their concerns about racism and inequality in college. Visibility may also transpire when black students feel that their needs are not met and concerns not considered. Correspondingly, this may indicate that black students feel silenced, unseen, unheard, and unimportant. These negative feelings can greatly impact their connections to their institutions, social interactions on campus, and their academic performance in the classroom. That is, black students and other students of color may be more prone to feeling "invisible" at their institutions because of other factors like racial 
separation, discrimination and prejudice. Previous research has not fully examined how black students' perceptions of visibility influences RSC or how it may reflect the RS-race process. However, it is important to examine this relationship because it stems from experiences and perceptions of discrimination and prejudice on college campuses that can influence the black students' RSC and well-being on college campuses.

\subsection{Other Factors Influencing Racial Self-Consciousness}

\section{The Possibility of Colorism}

Colorism is discrimination based on one's skin tone and may heighten students RS-race and RSC levels. Researchers often measure skin tone on a spectrum consisting of "very light," "light," "medium," "dark," or "very dark." In terms of discrimination, colorism results in several members of a race or ethnicity having more access to resources based on their skin tone forming a hierarchy or a "pigmentocracy" (BonillaSilva 2017). Although people of color face discrimination, they may experience varying degrees of discrimination depending how light or dark they appear or perceive themselves to be (Hunter, 2015; Monk, 2014; Monk, 2015).

Among black communities, previous research found that darker-skinned black Americans were more likely to be impoverished, have lower incomes, higher unemployment rates, and suffer from poorer health conditions than lighter-skinned black Americans (Bowman, Muhammad, \& Ifatunji, 2004; Harburg et al., 1978; Johnson, Farrell, \& Stoloff, 1998; Keith \& Herring, 1991; Krieger, Sidney, \& Coakley, 1998). These trends carry through research from the eighteenth century into the early twentyfirst century. Monk (2014) observed skin-tone stratification in education level, socio- 
economic status (SES), employment, marriage, spouse's education, geographical region, and skin color. Of 3,125 participants, African Americans of lighter complexions had higher incomes, higher levels of education, and more prestigious SESs than African Americans of darker complexions. Additionally, Monk (2014) found that black women with lighter complexions were more likely to marry more educated partners, and people of similar skin tones often marry one another.

In another study, Monk (2015) observed differences in mental and physical health based on skin tone among black and white Americans. Respondents with darker skin tones felt more discriminated against than respondents with lighter skin tones. Moreover, perceived discrimination elicits poorer mental health, such as depression, and physical health. Although this study does not address education, RSC or RS-race, it still sheds light on how skin tone affects perceived discrimination, and in turn affects one's mental and physical health.

Although many researchers observe colorism and status, only few observe this relationship in the classroom. There is little research speaking to how this trend occurs in the classroom. In their study regarding social interaction and access, Hunter (2015) examines skin color and discrimination using a combination of the halo effect, the beauty queue, racial capital, and the school-to-prison pipeline theories. According to Hunter (2015), discrimination based on skin color and skin tone in the classroom are forms of structural racism because of implicit bias. In the US education system, students' skin tones are consciously and unconsciously judged in everyday interactions with teachers, administrators, peers, and family-school relations. When these students are perceived as attractive, teachers, administrators, and other students deem them more intelligent, and 
are more willing to share educational and social opportunities for academic success (Hunter, 2015). This study also found black parents with lighter skin complexions are better able to advocate for their children because teachers and administrators better respect their concerns because of their phenotypical characteristics. This reality allows parents and guardians differential ability to advocate for their children, influencing their academic success. Hunter (2015) also found biracial students with white parents are more likely to have more academic success resulting from the preferential treatment lighter complexion students and parents receive in academic settings.

Colorism also applies to the school-to-prison pipeline for black students. When considering the implicit bias of teachers and administrators, black students receive harsher disciplinary actions in the school system, and are more quickly punished compared to their white peers (Okonofua \& Eberhardt, 2015). Degrees of colorism only worsen the school-to-prison pipeline as Hunter (2015) found students with darker complexions were more harshly disciplined in both educational institutions and the courts. Drawing from this research, colorism greatly impacts black people's lives in and outside the classroom (Hunter, 2015; Monk, 2014; Monk, 2015; Okonofua \& Eberhardt, 2015), and can influence students' experiences when they enter college. Thus, I posit that colorism may trigger black students' racial self-consciousness or race-based rejection sensitivity levels despite being underexplored in previous research.

\section{Closeness and Worldviews}

Stronger connections to groups, particularly members of one's own racial group, through perceiving one's worldview, or how their thoughts and feelings align with group members, can be an important component of identity and navigating college campuses 
for students (see Byrd 2017). Despite the importance of feeling a connection to other group members, Koehler and Skvoretz (2010) found African American students can feel varying degrees of isolation on campus despite developing a sense of closeness to their black peers during their first year. For example, an out-of-state female student stated that she felt uncomfortable with the racial separation on campus because it limited her friend group. The racial mores surrounding separation indicated that she was to interact with other black peers on campus; however, she was not in the friend groups that had existed within her race because she was an out-of-state student. Thus, not all black students feel a sense of closeness to other African Americans at higher education institutions. This reality can impact how they understand discrimination and black students' experiences more broadly on campus, and how this impacts their self-consciousness.

Scholars have examined how one's cultural pride changes RS-race levels. Telesford et al. (2013) found that if African American students have more pride in their culture, they show higher levels of RS-race, or vigilance toward their university at historically white colleges and universities (see also Mendoza-Denton \& Page-Gould, 2008). While these findings show an interesting occurrence, scholars studying the relationship between cultural pride and trust fail to recognize confounding variables that may play a role in how RS-race manifests. For instance, as black students become more culturally competent, they learn that higher education institutions have historically marginalized black people and other peoples of color (see Wilder, 2013). This fact alone may inhibit student trust in the institution and increase student RS-race simultaneously. So, attributing black students' RS-race to their cultural pride is a defective assertion. We should instead attribute RS-race to structural issues, such as historic racial 
marginalization at US college campuses and universities, and view RS-race as a symptom of this structural racism. As Hensen, Derlega, and Pearson (2013) found, black students with stronger ethnic identities in college also had lower levels of RS-race. Therefore, the current study examines how black students' worldview in relation to the broader black community may somewhat encapsulate cultural pride while also making connections to the realities of racial discrimination on campus in society that can influence both RS-race and RSC levels.

Researchers have uncovered how black students' worldview or closeness to other black community members shapes their RS-race levels during college (Telesford, et al., 2013). However, these studies often focus on black cultural pride, rather than worldview. Other black college students claim that their heightened race consciousness motivated them to reach out to other black people on campus. Students were proud of the black faculty and staff on campus, and found solace in their BSU, black studies program, and black Greek life (Brooms, 2017; Koehler \& Skovoretz, 2010). They felt closer to other black people on campus because of their increased racial self-consciousness and/or racebased rejection sensitivity.

\subsection{Hypotheses}

Building on previous studies, I hypothesize several trends for the current study. These hypotheses focus on the relationships between the RS-race processes embedded within campus climates and black students' RSC levels during college. The first is a significant linear relationship between perceived racial discrimination and RSC and RSrace, with a slope not equal to zero, meaning increased racial discrimination results in increased RSC/RS-race. Next, I hypothesize a significant linear relationship between 
perceived campus commitment to racial diversity and RSC and RS-race, with a slope not equal to zero. This means the more black students think their colleges commit to racial diversity, the less RSC and RS-race these students experience. I also predict a significant linear relationship between perceived racial separation and RSC and RS-race, with a slope not equal to zero, which means the more black students see racial separation at their colleges the more RSC and RS-race they experience. I expect a significant linear relationship between perceived black student visibility and RSC and RS-race, with a slope not equal to zero, where the more black student visibility respondents perceive the less RSC and RS-race they experience. Next, I predict a significant linear relationship between racial prejudice and RSC/RS-race, with a slope not equal to zero, meaning as racial prejudice increases RSC and RS-race increases. I also expect a significant linear relationship between skin color and RSC and RS-race, with a slope not equal to zero, where darker-skinned students are more likely to experience RSC and RS-race than lighter-skinned students. Lastly, I hypothesize a significant linear relationship between perceived closeness to blacks and RSC and RS-race, with a slope not equal to zero, meaning the closer respondents feel to black the more RSC and RS-race they display.

$H_{1}$ : Higher levels of experienced and perceived racial discrimination will increase black students' racial self-consciousness levels.

$\mathrm{H}_{2}$ : Lower levels of perceived institutional commitment to racial diversity will increase black students' racial self-consciousness levels.

$H_{3}$ : Higher levels of perceived racial separation on campus will increase black students' racial self-consciousness levels. 
$H_{4}$ : Higher levels of perceived black student visibility will decrease black students' racial self-consciousness levels. 


\section{CHAPTER 3: METHODOLOGICAL APPROACH}

\subsection{Dataset}

The data for the current study are part of the National Longitudinal Survey of Freshmen (NLSF). The NLSF collected information from black, white, Asian and Pacific Islander, and Latino students from 28 of the most selective colleges and universities (as measured by SAT scores, class rank, and U.S. News and World Report rankings) to better comprehend minority academic performance. These institutions varied regarding the size of their black student populations (i.e. schools with over 1,000 black students, between 500 and 1,000 black students, between 100 and 500 black students, and less than 100 black students), and the type of institutions attended included liberal arts colleges, private research universities, and public research universities. Respondents were followed for four years while pursuing their bachelor's degrees from fall 1999 through spring 2003. Observations were made over the course of five waves, the first of which occurred before the students entered college. Of the 1,051 self-identified black students in the dataset, I examined 796 who completed their college experience at the same institution they entered. Students had "US citizenship" status, or "resident alien" status. The NLSF contains a wealth of information about the college student experience including measures corresponding to race-based rejection sensitivity levels, racial self-consciousness, commitment to racial diversity on campus, and the degree of racial separation on campus, 
among other measures that can clarify how black students can develop high levels of rejection sensitive and self-consciousness levels.

\subsection{Measures}

Racial self-consciousness. A scale was created to measure students' racial selfconsciousness (RSC) using eight items across three waves of data collection. In wave 2, students were asked how frequently they felt self-conscious about their race in the following situations: (1) "How often, if ever, have students in your college classes ever made you feel uncomfortable or self-conscious because of your race or ethnicity?”, (2) "How often, if ever, have any of your college professors made you feel uncomfortable or self-conscious because of your race or ethnicity?", and (3) "Walking around campus, how often, if ever, have you been made to feel uncomfortable or self-conscious because of your race or ethnicity?" Three similar questions were asked of students in wave 3: (1) "Since the beginning of the Fall 2000 term, how often, if ever, have students in college classes made you feel uncomfortable or self-conscious because of your race or ethnicity?”, (2) “How often, if ever, have any of your college professors made you feel uncomfortable of self-consciousness because of your race or ethnicity?", and (3) "Walking around campus, how often if ever, have you been made to feel uncomfortable or self-conscious because of your race or ethnicity?" Two similar questions were asked in wave 4: (1) "Since the beginning of the Fall Term, how often, if ever, have you felt uncomfortable of self-conscious because of your race or ethnicity?", and (2) "How often, if ever, have you been made to feel uncomfortable or self-conscious walking around campus because of your race or ethnicity?" Students responded to each question on a scale from "never" (1) to "very often" (5). To create a proximate scale of RSC during 
college, the eight items were added together and then divided by the total number of items (range $1-5 ; \alpha=.865)$. An additional dichotomous variable $(1=$ yes; $0=$ no) was created identifying if students scored high on the RSC scale by identifying those students whose scores were at least one standard deviation above mean. That is, students identified with high levels of RSC during college scored at least 2.50 on the scale.

Racial discrimination on campus. A scale was established to measure students' experiences and perceptions of racial discrimination during college. This scale serves as a proximate measure for race-based rejection sensitivity (RS-race). Eighteen (18) Likert scale items were used to construct the scale. Students were asked to rate their perceptions and experiences of discrimination from "never" (1) to "very often" (5). The questions were: (1) "How often, if ever, have you felt you were given a bad grade by a professor because of your race or ethnicity?" in wave two, (2) "How often, if ever, have you felt you were discouraged by a professor from speaking out in class because of your race or ethnicity?" in wave two, (3) "How often, if ever, have you been discouraged from a course of study by your professor?" in wave two, (4) "How often, if ever, have you felt you were given a bad grade by a professor because of your race or ethnicity?" in wave three, (5) "How often, if ever, have you felt you were discouraged by a professor from speaking out in class because of your race or ethnicity?" in wave three, (6) "How often, if ever, have you been discouraged from a course of study by your professor?" in wave three, (7) "How often, if ever, have you felt you were given a bad grade by a professor because of your race or ethnicity?" in wave four, (8) “How often, if ever, have you felt you were discouraged by a professor from speaking out in class because of your race or ethnicity?" in wave four, (9) "How often, if ever, have you heard derogatory remarks 
made by fellow students about your racial or ethnic group?" in wave two, (10) "How often, if ever, have you heard derogatory remarks made by professors about your racial or ethnic group?" in wave two, (11) "How often, if ever, have you heard derogatory remarks by other college staff about your racial or ethnic group?" in wave two, (12) "How often, if ever, have you experienced any other form of harassment on campus simply because of your race or ethnicity?" in wave two, (13) "How often, if ever, have you heard derogatory remarks made by fellow students about your racial or ethnic group?" in wave three, (14) "How often, if ever, have you heard derogatory remarks made by professors about your racial or ethnic group?" in wave three, (15) "How often, if ever, have you heard derogatory remarks by other college staff about your racial or ethnic group?" in wave three, (16) "How often, if ever, have you experienced any other form of harassment on campus simply because of your race or ethnicity?" in wave three, and (17) "How often, if ever, have you heard derogatory remarks mad about your racial or ethnic group?" To create the proximate scale of racial discrimination and prejudice, the 18 items were added together then divided by the total number of items (range $1-5 ; \alpha=.835$ ).

Commitment to racial diversity. Students' perceptions of their institution's commitment to racial diversity was measured using a Likert scale item ranging from "way too much" (1) to "way too little" (5). Respondents were asked, "How do you see (name of most recent college attended)'s commitment to racial and ethnic diversity of campus?"

Racial separation. Students were asked their perceptions about the degree of racial separation on campus. Specifically, students responded to the following question: "How would you characterize the degree of racial separation on the campus of (name of 
most recent college attended)?" Responses ranged from "very little" (1) to "very substantial" (5).

Black student visibility. Perceptions of black student visibility were measured using a Likert scale from "strongly disagree" (0) to "strongly agree" (10). Participants were asked, “... to what extent do you disagree or agree with the following statement: Black students are visible on campus." This question was only asked at the end of students' college experience (Wave 5), and can be considered a retrospective measure of their experiences on campus.

Control variables. A variety of control variables were included in the analyses. The measures included gender $(1=$ female; $0=$ male $)$ and nationality $(1=$ non-U.S. citizen; $0=$ U.S. citizen) of students, dichotomous measures for each region of country (i.e., Northeast, Midwest, South, and West), type of high school attended before college (1= private; $0=$ public), and two measures estimating the segregation of their communities and schools $(1=$ segregated neighborhood $/$ school; $2=$ mixed neighborhood $/$ school; $3=$ integrated neighborhood/school). A segregated neighborhood or school included more than $70 \%$ of the residents or students composed of black and Latinos. An integrated neighborhood or school included between $30 \%$ and $69 \%$ of the residents or students composed of black and Latinos. An integrated neighborhood or school included less than $30 \%$ of residents or students composed of blacks and Latinos. Three dichotomous measures $(1=$ yes; $0=$ no $)$ for whether they attended a liberal arts college, public research university, or a private research university were also included in the analyses.

Information about family income and education was included in this study. In relation to family income data collected during wave 3, respondents asked "In thinking 
about household income you should include the wages and salaries of all household members, plus any self-employment income they may have had, along with interest, dividends, alimony payment, social security, and pensions," and were asked "What is you parent or guardian's household annual income?” ( $1=$ less than $\$ 20,000 ; 2=\$ 20,000$ $\$ 24,999 ; 3=\$ 25,000-\$ 34,999 ; 4=\$ 35,000-\$ 49,999 ; 5=\$ 50,000-\$ 74,999 ; 6=\$ 75,000-$ $\$ 99,999 ; 7=\$ 100,000-\$ 124,999 ; 8=\$ 125,000-\$ 149,999 ; 9=\$ 150,000-\$ 174,999 ; 10=$ $\$ 175,000-\$ 199,999 ; 11=$ more than $\$ 200,000)$. Parental education level was measured with two questions where researchers asked, "what is the highest level of schooling achieved by your mother or the woman most responsible for raising you?" and "What is the higher level of schooling achieved by your father or the man most responsible for raising you?" (1= grade school, $2=$ some high school, $3=$ high school graduate, $4=$ some college, $5=$ college graduate, $6=$ some post-graduate, $7=$ graduate or professional degree) .

Two additional characteristics of students important to consider are skin color and their perceived closeness toward other blacks. Skin color was measured during wave 1 using one-item Likert scale. Researches were asked, "To the best of your ability, give your judgment as to the lightness or darkness of the respondent's skin color," to determine participants' skin color. The scale ranged from "very light" (0) to "very dark" (10). The closeness to other blacks among students was determined in waves 1 and 5 by asking respondents' how similar they thought their worldview was to other blacks. In wave 1 , closeness was measured using a 6-item scale ranging from "very distant" (0) to "very close" (10). Student participants were asked to rate their closeness to (1) "African Americans," (2) “young African American men," (3) “young African American women," (4) "poor African Americans," (5) "middle-class African Americans," and (6) "rich 
African Americans." Similarly, in wave 5, respondents were asked how close they felt their worldview was to five groups: (1) "blacks," (2) "poor blacks," (3) "middle-class blacks," (4) "black students at (name of most recent college attended)," and (5) "rich blacks". Two closeness scales were created. The first scale included the summation of all wave 1 items and then divided by the total, while the second scale included the summation of all wave 5 closeness items and divided by the total as well.

\subsection{Statistical Analyses}

The current study utilized different statistical analyses to examine the factors influencing black students' race-based rejection sensitivity levels during college. First, I computed the descriptive statistics for each measure included in the study. These statistics include the means and standard deviations for each measure included in the study. Second, I analyzed the relationship between the control variables and the four campus climate-related processes of race-based rejection sensitivity using ordinary least squares (OLS) regression models. The four models used the overall racial discrimination scale, perception of institutional commitment to diversity, perception of racial separation on campus, and perception of black student visibility on campus as dependent variables. Each of these models included the following background variables: gender, skin color, whether a student was an international student, closeness to blacks at college entry, family income, parental education level, school and neighborhood segregation levels, private high school attendance, region, and whether students attended a private research university or liberal arts college. Reference categories for these models included black men, U.S. students, attending a public high school prior to college enrollment, residing in the South prior to college enrollment, and attending a public research university. 
Third, I constructed a series of OLS regression models to examine how each form campus climate-related process of race-based rejection sensitivity influenced black students' racial self-consciousness (RSC) levels. Model 1 only included the students' background characteristics similar to the models described above with the addition of the second closeness scale collected at the end of college. Then, in succeeding models (Models 2-5) I included each measure related to race-based rejection sensitivity separately to identify how each measure influenced students' RSC levels. In Model 6, I included all four measures together to identify how students' RSC levels differed when considering the full group of campus climate-related measures.

Fourth, I conducted means comparisons (t-tests) to identify differences between black students who had high RSC levels and those that did not. Lastly, I conducted binomial logistic regressions with the dichotomous measure of whether students had high RSC levels or not as the dependent variable. I constructed six models similar to the above OLS regression models with first model only including students' background characteristics, then separate models for each race-based rejection sensitivity measure related to the campus climate, and then lastly a full model with all measures included in the analysis. Again, reference categories for these models included black men, U.S. students, attending a public high school prior to college enrollment, residing in the South prior to college enrollment, and attending a public research university. 


\section{CHAPTER 4: FACTORS INCREASING RACE-BASED REJECTION SENSITIVTY AND RACIAL SELF-CONSCIOUS AMONG BLACK STUDENTS}

Table 1 shows the descriptive statistics for racial self-consciousness, campus climate measures related to rejection sensitivity, and respondents' background characteristics. Of the 796 black college students in the sample, the mean racial selfconsciousness and discrimination levels were relatively low. Over half of black college students felt that their institutions were less committed to racial diversity. Students also perceived substantial racial separation and felt that black students were mildly visible on their college campuses. 
Table 1. Descriptive statistics of NLSF black students

\begin{tabular}{|c|c|c|c|}
\hline Variable & Mean & SD & Range \\
\hline \multicolumn{4}{|l|}{ Racial self-consciousness } \\
\hline RSC Scale & 1.84 & 67 & $1-5$ \\
\hline \multicolumn{4}{|l|}{ Campus climate } \\
\hline Racial discrimination scale & 1.37 & .34 & $1-5$ \\
\hline $\begin{array}{l}\text { College diversity } \\
\text { commitment }\end{array}$ & 3.49 & .93 & $1-5$ \\
\hline $\begin{array}{l}\text { Racial separation on } \\
\text { campus }\end{array}$ & 3.35 & 1.08 & $1-5$ \\
\hline Black student visibility & 6.48 & 2.69 & $1-10$ \\
\hline \multicolumn{4}{|l|}{ Background characteristics } \\
\hline Gender (1= woman) & .68 & 47 & $0-1$ \\
\hline Skin color & 4.96 & 2.14 & $0-10$ \\
\hline Non-U.S. born & .08 & .28 & $0-1$ \\
\hline $\begin{array}{l}\text { Closeness to blacks at } \\
\text { college exit }\end{array}$ & 6.25 & 1.49 & $0-10$ \\
\hline $\begin{array}{l}\text { Closeness to blacks at } \\
\text { college entry }\end{array}$ & 6.69 & 1.57 & $0-10$ \\
\hline Parental income & 5.13 & 2.52 & $1-11$ \\
\hline Mother's education & 4.96 & 1.51 & $1-7$ \\
\hline Father's education & 5.06 & 1.58 & $1-7$ \\
\hline Private high school & .30 & .46 & $0-1$ \\
\hline School segregation & 1.79 & .79 & $1-3$ \\
\hline Neighborhood segregation & 1.97 & .89 & $1-3$ \\
\hline Northeast & .32 & 47 & $0-1$ \\
\hline Midwest & .24 & .43 & $0-1$ \\
\hline South & .27 & .44 & $0-1$ \\
\hline West & .14 & .35 & $0-1$ \\
\hline Private research university & .57 & .50 & $0-1$ \\
\hline Public Research University & .35 & .48 & $0-1$ \\
\hline Liberal arts college & .11 & .31 & $0-1$ \\
\hline $\mathrm{N}$ & 796 & & \\
\hline
\end{tabular}


There were more black women than black men in the sample. Most people in the sample did not have very dark skin complexions, and most were born with US nationality. Black college students felt slightly closer to other black people when they started college than when they graduated from their colleges and universities. Many of the student respondents came from households with parental income between $\$ 50,000$ and \$74,999 earned per year. In most cases, the students' mothers attended college but did not complete their degrees, while their fathers were college graduates. Under half of black college students in the sample graduated from private high schools. Also, most students graduated from segregated high schools and neighborhoods. While most of the black college students in the sample came from the Northeast region, many came from the South, and the Midwest. The least number of students came from the West. More black students attended private research universities than public research universities and liberal arts colleges, and more students attended public research universities than liberal arts colleges.

Table 2 presents the regression models for each campus climate measure related to rejection sensitivity. The first model examined the background characteristics influencing students' experiences and perceptions of racial discrimination on campus and explained one percent of the variation in racial discrimination experiences among black students. Only one variable influenced students' racial discrimination experiences and perceptions during college. Students with darker complexions experienced more discrimination during college. 
Table 2. Predictors of race-based rejection sensitivity processes of campus climate

\begin{tabular}{|c|c|c|c|c|c|c|c|c|}
\hline Variable & \multicolumn{2}{|c|}{ Racial Discrimination } & \multicolumn{2}{|c|}{$\begin{array}{c}\text { Institutional Diversity } \\
\text { Commitment }\end{array}$} & \multicolumn{2}{|c|}{$\begin{array}{c}\text { Campus Racial } \\
\text { Separation }\end{array}$} & \multicolumn{2}{|c|}{$\begin{array}{c}\text { Black Student } \\
\text { Visibility }\end{array}$} \\
\hline \multicolumn{9}{|l|}{ Background characteristics } \\
\hline Skin color & $.10 *$ & .01 & $.16^{* * *}$ & .02 & -.02 & .02 & $-.15 * *$ & .06 \\
\hline Non-U.S. born & .02 & .06 & -.03 & .16 & .08 & .18 & -.02 & .46 \\
\hline Closeness to blacks at college entry & .08 & .01 & .07 & .03 & .03 & .03 & .03 & .08 \\
\hline Father's education & -.08 & .01 & -.06 & .04 & -.04 & .04 & .01 & .10 \\
\hline Private high school & -.01 & .04 & .05 & .11 & .01 & .13 & -.00 & .32 \\
\hline School segregation & .07 & .03 & -.01 & .07 & .02 & .08 & -.01 & .20 \\
\hline Neighborhood segregation & .01 & .02 & .07 & .06 & .02 & .07 & -.02 & .17 \\
\hline Northeast & .05 & .05 & .03 & .12 & .02 & .13 & .01 & .34 \\
\hline Midwest & .08 & .05 & -.02 & .12 & .10 & .13 & $-.16^{* *}$ & .34 \\
\hline Constant & $1.03 * * *$ & .13 & $2.63 * * *$ & .33 & $2.85 * * *$ & .38 & $7.72 * * *$ & .97 \\
\hline Adjusted $\mathrm{R}^{2}$ & .01 & & .04 & & .01 & & .05 & \\
\hline $\mathrm{N}$ & 467 & & 461 & & 475 & & 461 & \\
\hline
\end{tabular}


The second model examined the influence of students' background characteristics on their perceptions of their institution's commitment to racial diversity, and explained four percent of the variation in these views. Again, few variables influenced students' views. Black women felt their institutions were less committed to racial diversity than black men. Also, students with dark skin felt their institutions were less committed to racial diversity. The third model examined how students' background characteristics influenced their views of racial separation on campus, and explained one percent of variation in these views. Only one variable influenced students' views on this aspect of campus. Students who attended a private research university perceived more racial separation on-campus compared to their peers at public research universities. The fourth model examined how students' characteristics influenced their perceptions of black students' visibility on campus, and explained five percent of variation in black student visibility on campus. Students with darker skin complexions perceived black students were less visible on campus. Students from the Midwest also perceived black students were less visible on campus compared to their peers from the South. In relation to where students attended college, students attending private research universities and liberal arts colleges perceived black students were less visible on campus compared to their peers at public research universities. The remaining background characteristics did not influence students' perceptions of black student visibility on campus. The influence of each campus climate measure on black students' racial self-consciousness levels are explored in Table 3. The first model provides a baseline comparison for other models by examining students' background characteristics on their racial self-consciousness levels. This first model explained three percent of the variation in student racial self-consciousness levels. 
Students with darker skin complexions had higher levels of racial self-consciousness at the end of college. Also, students from the Midwest had higher levels of racial selfconsciousness compared to their peers from the South. Students attending private research universities and liberal arts colleges had higher levels of racial selfconsciousness compared to their peers at public research universities. None of the remaining background characteristics were significant. 
Table 3. OLS regression models of race-based rejection sensitivity processes on racial self-consciousness

\begin{tabular}{|c|c|c|c|c|c|c|c|c|c|c|}
\hline \multirow[b]{2}{*}{ Variables } & \multicolumn{2}{|c|}{ Model 1} & \multicolumn{2}{|c|}{ Model 2} & \multicolumn{2}{|c|}{ Model 3} & \multicolumn{2}{|c|}{ Model 4} & \multicolumn{2}{|c|}{ Model 5} \\
\hline & $\beta$ & $\mathrm{SE}$ & $\beta$ & $\mathrm{SE}$ & $\beta$ & $\mathrm{SE}$ & $\beta$ & $\mathrm{SE}$ & $\beta$ & $\mathrm{SE}$ \\
\hline \multicolumn{11}{|l|}{ Campus climate } \\
\hline Racial discrimination scale & ---- & ---- & $.70 * * *$ & .07 & ---- & ---- & ---- & ---- & ---- & ---- \\
\hline $\begin{array}{l}\text { College diversity } \\
\text { commitment }\end{array}$ & ---- & ---- & ---- & ---- & .05 & .04 & ---- & ---- & ---- & ---- \\
\hline Racial separation on campus & ---- & ---- & ---- & ---- & ---- & ---- & $.33 * * *$ & .03 & ---- & ---- \\
\hline Black student visibility & ---- & ---- & ---- & ---- & ---- & ---- & ---- & ---- & $-.28 * * *$ & .01 \\
\hline \multicolumn{11}{|l|}{ Background characteristics } \\
\hline Gender (1= woman) & .03 & .07 & .04 & .05 & .30 & .07 & .30 & .07 & .05 & .07 \\
\hline Skin color & $.11^{*}$ & .02 & .05 & .01 & $.10 *$ & .02 & $.12 * *$ & .02 & .07 & .02 \\
\hline Non-U.S. born & .03 & .12 & .02 & .09 & .03 & .12 & -.01 & .12 & .03 & .11 \\
\hline $\begin{array}{l}\text { Closeness to blacks at } \\
\text { college exit }\end{array}$ & .04 & .03 & .01 & .02 & .03 & .03 & .07 & .03 & .05 & .03 \\
\hline $\begin{array}{l}\text { Closeness to black at college } \\
\text { entry }\end{array}$ & -.02 & .02 & -.05 & .02 & -.03 & .02 & -.04 & .02 & -.01 & .02 \\
\hline Parental income & .04 & .02 & .00 & .01 & .04 & .02 & .05 & .02 & .05 & .02 \\
\hline Mother's education & .03 & .03 & -.01 & .02 & .03 & .03 & .02 & .03 & .02 & .03 \\
\hline Father's education & -.05 & .03 & -.03 & .02 & -.05 & .03 & -.05 & .03 & -.04 & .03 \\
\hline Private high school & .02 & .09 & .02 & .06 & .02 & .09 & .01 & .08 & .02 & .09 \\
\hline School segregation & .09 & .06 & .06 & .04 & .09 & .06 & .09 & .05 & .09 & .05 \\
\hline Neighborhood segregation & .07 & .05 & .06 & .03 & .08 & .05 & .06 & .05 & .07 & .05 \\
\hline Northeast & .07 & .09 & .03 & .06 & .06 & .09 & .06 & .09 & .07 & .09 \\
\hline Midwest & $.15^{* *}$ & .09 & $.18^{*}$ & .07 & $.15^{* *}$ & .09 & .10 & .09 & .10 & .09 \\
\hline West & .10 & .02 & .04 & .08 & .10 & .12 & .08 & .11 & .08 & .11 \\
\hline Private research university & $.15^{* *}$ & .08 & $.11 * *$ & .05 & $.15^{* *}$ & .08 & $.10^{*}$ & .07 & $.10^{*}$ & .07 \\
\hline Liberal arts college & $.14^{* *}$ & .12 & $.14 * * *$ & .09 & $.14^{* *}$ & .12 & $.12 *$ & .12 & .08 & .12 \\
\hline Constant & 1.04 & .28 & -.31 & .21 & $.97 * * *$ & .29 & .36 & .28 & $1.59 * * *$ & .28 \\
\hline Adjusted $\mathrm{R}^{2}$ & .03 & & .53 & & .03 & & .14 & & .11 & \\
\hline $\mathrm{N}$ & 414 & & 412 & & 413 & & 413 & & 413 & \\
\hline
\end{tabular}

$* p<.05 ; * * p<.01 ; * * * p<.001$. 
The second model included the racial discrimination scale and explained 53 percent of the variation in student racial self-consciousness levels. Students who faced more racial discrimination on campus experienced more racial self-consciousness. Similar to the previous model, students from the Midwest and those attending private research universities and liberal arts colleges also had higher levels of racial selfconsciousness at the end of college. The third model included students' perceptions of their institutions' commitment to racial diversity and explained three percent of the variation in student racial self-consciousness levels. However, the perception of how committed their institution was to racial diversity did not influence their racial selfconsciousness levels. Students with darker skin complexions had higher levels of racial self-consciousness. Again, students from the Midwest and those attending private research universities and liberal arts colleges also had higher levels of racial selfconsciousness at the end of college. The remaining background characteristics were not significant. The fourth model included students' perceptions of racial separation on campus and explained 14 percent of the variation in student racial self-consciousness levels. Students who perceived more racial separation on campus had higher levels of racial self-consciousness. Also, students who had darker skin complexions, and those who attended private research universities and liberal arts colleges had higher levels of racial self-consciousness. Similar to previous models, none of the remaining background characteristics were significant in the model.

The fifth model included students' perceptions of black student visibility on campus and explained 11 percent of the variation in student racial self-consciousness 
levels. Students who perceived black students as more visible on campus had lower levels of racial self-consciousness at the end of college. Among the remaining variables included in the model, only one influenced students' racial self-consciousness levels. Students who attended a private research university had higher levels of racial selfconsciousness compared to their peers at public research universities. In the sixth and final model, all four campus climate measures were included in the analyses, and this model explained 57 percent of the variation in student racial self-consciousness levels. The campus climate measures were the central influence in the model as students who experienced and perceived more racial discrimination in college, and those who perceived more racial separation on campus had higher levels of racial self-consciousness at the end of college. Students who perceived black students as more visible on campus had lower levels of racial self-consciousness. Only one of the background characteristics was significant in this final model as students who attended liberal arts colleges had higher levels of racial self-consciousness compared to their peers at public research universities.

These findings suggest that rejection sensitivity as measured through the four campus climate measures can significantly influence students' racial self-consciousness levels at the end of college. However, it raises the question of how important these campus experiences are to tipping students into what could be considered a high level of racial self-consciousness. In the next chapter, I explore the characteristics of black students who have high levels of racial self-consciousness and what can lead students to fall into this group at the end of college. 
CHAPTER 5: THE TIPPING POINT: EXAMINING BLACK STUDENTS WITH HIGH RACE-BASED REJECTION SENSITIVITY LEVELS AND SELF CONSCIOUNESS

In order to compare black students who had high levels of racial selfconsciousness in relation to their peers who did not, two groups were created to examine using means comparisons. As shown in Table 4, these comparisons indicate that black students with high levels of racial self-consciousness experience more racial discrimination than their peers. They also perceive more racial separation on campus than black students without high levels of racial self-consciousness. Students with high levels of racial self-consciousness felt that black students are less visible on campus than students without high levels of racial self-consciousness. Black students with high levels of racial self-consciousness were less likely to attend private high schools. However, black students with high levels of racial self-consciousness were more likely to experience segregation in their schools and neighborhoods. The remaining comparisons between the two student groups indicate that these students did not significantly differ in their backgrounds or their views of institutional commitment to racial diversity on campus. 
Table 4. Means comparisons of differing racial self-consciousness levels among black students

\begin{tabular}{|c|c|c|c|}
\hline \multirow[b]{2}{*}{ Variable } & \multicolumn{2}{|c|}{$\begin{array}{c}\text { Racial Self-Consciousness } \\
\text { Levels }\end{array}$} & \multirow{2}{*}{$\begin{array}{c}\text { Means } \\
\text { Comparison } \\
\text { H-NH }\end{array}$} \\
\hline & High & Not High & \\
\hline \multicolumn{4}{|l|}{ Campus climate } \\
\hline Racial discrimination scale & 1.84 & 1.29 & $.55 * * *$ \\
\hline College diversity commitment & 3.58 & 3.45 & .13 \\
\hline Racial separation on campus & 3.91 & 3.26 & $.65^{* * *}$ \\
\hline Black student visibility & 5.42 & 6.66 & $-1.24 * * *$ \\
\hline \multicolumn{4}{|l|}{ Background characteristics } \\
\hline Gender (1= woman $)$ & .66 & .69 & -.03 \\
\hline Skin color & 5.26 & 4.97 & .29 \\
\hline Non-U.S. born & .08 & .09 & -.01 \\
\hline Closeness to blacks at college exit & 6.43 & 6.22 & .21 \\
\hline $\begin{array}{l}\text { Closeness to blacks at college } \\
\text { entry }\end{array}$ & 6.84 & 6.67 & .17 \\
\hline Parental income & 5.04 & 5.15 & -.11 \\
\hline Mother's education & 4.91 & 5.01 & -.10 \\
\hline Father's education & 4.82 & 5.07 & -.25 \\
\hline Private high school & .20 & .30 & $-.10 *$ \\
\hline School segregation & 1.99 & 1.77 & $.22 * *$ \\
\hline Neighborhood segregation & 2.18 & 1.95 & $.23 *$ \\
\hline Northeast & .30 & .33 & -.03 \\
\hline Midwest & .25 & .23 & .02 \\
\hline South & .26 & 28 & -.02 \\
\hline West & .16 & .13 & .03 \\
\hline Public research university & .29 & .33 & -.04 \\
\hline Private research university & .62 & .57 & .05 \\
\hline Liberal arts college & .10 & .10 & .00 \\
\hline $\mathrm{N}$ & 109 & 637 & \\
\hline
\end{tabular}


Table 5 presents the binomial logistic regression models examining the influence of campus climate experiences and perceptions as well as students' background characteristics on their likelihood of having high levels of racial self-consciousness. The first model only included students' background characteristics and explained three percent of the variance in students with high levels of racial self-consciousness. However, none of the background characteristics influenced the likelihood that students had high levels of racial self-consciousness. 
Table 5. Logistic regression models of race-based rejection sensitivity processes high levels of racial self-consciousness

\begin{tabular}{|c|c|c|c|c|c|c|c|c|c|c|}
\hline \multirow[b]{2}{*}{ Variables } & \multicolumn{2}{|c|}{ Model 1} & \multicolumn{2}{|c|}{ Model 2} & \multicolumn{2}{|c|}{ Model 3} & \multicolumn{2}{|c|}{ Model 4} & \multicolumn{2}{|c|}{ Model 5} \\
\hline & Coef. & OR & Coef. & OR & Coef. & OR & Coef. & OR & Coef. & OR \\
\hline Racial discrimination scale & ---- & ---- & $5.04 * * *$ & 154.71 & ---- & ---- & ---- & ---- & ---- & ---- \\
\hline Racial separation on campus & ---- & ---- & ---- & ---- & ---- & ---- & $.82 * * *$ & 2.27 & ---- & ---- \\
\hline Black student visibility & ---- & ---- & ---- & ---- & ---- & ---- & ---- & ---- & $-.13^{*}$ & .88 \\
\hline \multicolumn{11}{|l|}{ Background characteristics } \\
\hline Skin color & .06 & 1.06 & .03 & 1.03 & .04 & 1.04 & .06 & 1.06 & .02 & 1.02 \\
\hline Non-U.S. born & -.28 & .76 & -.27 & .76 & -.24 & .79 & -.67 & .51 & -.29 & .75 \\
\hline $\begin{array}{l}\text { Closeness to blacks at college } \\
\text { exit }\end{array}$ & .13 & 1.14 & .11 & 1.12 & .11 & 1.12 & .18 & 1.19 & .12 & 1.13 \\
\hline $\begin{array}{l}\text { Closeness to blacks at college } \\
\text { entry }\end{array}$ & .00 & 1.00 & -.00 & 1.00 & -.01 & .99 & -.03 & .97 & .00 & 100 \\
\hline School segregation & .18 & 1.20 & .18 & 1.20 & .15 & 1.16 & .18 & 1.19 & .16 & 1.18 \\
\hline Neighborhood segregation & .27 & 1.31 & .45 & 1.56 & .30 & 1.35 & .26 & 1.30 & .29 & 1.33 \\
\hline Northeast & .16 & 1.18 & -.19 & .83 & .09 & 1.09 & .19 & 1.21 & .14 & 1.15 \\
\hline Midwest & .43 & 1.54 & .06 & 1.06 & .43 & 1.54 & .25 & 1.29 & .33 & 1.39 \\
\hline West & .37 & 1.44 & -.20 & .82 & .34 & 1.40 & .21 & 1.23 & .28 & 1.32 \\
\hline Private research university & .46 & 1.58 & .44 & 1.56 & .41 & 1.51 & .27 & 1.31 & .32 & 1.38 \\
\hline Liberal arts college & .40 & 1.49 & .64 & 1.90 & .40 & 1.49 & .33 & 1.38 & .16 & 1.17 \\
\hline Constant & $-4.04 * * *$ & .02 & $-10.76^{* * *}$ & .00 & $-4.00 * *$ & .02 & $-6.97 * * *$ & $.00 *$ & $-2.96 *$ & .05 \\
\hline Log-likelihood & 336.19 & & 212.12 & & 332.77 & & 311.54 & & 327.64 & \\
\hline Psuedo- $\mathrm{R}^{2}$ & .03 & & .28 & & .03 & & .09 & & .04 & \\
\hline $\mathrm{N}$ & 414 & & 412 & & 413 & & 413 & & 413 & \\
\hline
\end{tabular}

$* p<.05 ; * * p<.01 ; * * * p<.001$. 
Table 5 continued. Binomial logistic regression of race-based rejection sensitivity processes on high levels of racial self-consciousness among black students

\begin{tabular}{lcr}
\hline \multicolumn{1}{c}{ Variable } & \multicolumn{2}{c}{ Model 6 } \\
\cline { 2 - 3 } Campus climate & Coef. & OR \\
Racial discrimination scale & & \\
College diversity commitment & $4.83^{* * *}$ & 125.11 \\
Racial separation on campus & -.06 & .94 \\
Black student visibility & $.45^{*}$ & 1.57 \\
Background characteristics & -.04 & .96 \\
Gender (1= woman) & & \\
Skin color & -.38 & .68 \\
Non-U.S. born & .01 & 1.01 \\
Closeness to blacks at college exit & -.43 & .65 \\
Closeness to blacks at college entry & .10 & 1.10 \\
Parental income & -.02 & .98 \\
Mother's education & .08 & 1.08 \\
Father's education & -.12 & .89 \\
Private high school & -.07 & .93 \\
School segregation & -.59 & .55 \\
Neighborhood segregation & .18 & 1.20 \\
Northeast & .49 & 1.63 \\
Midwest & -.36 & .70 \\
West & -.10 & .91 \\
Private research university & -.34 & .71 \\
Liberal arts college & .24 & 1.28 \\
Constant & .43 & 1.53 \\
Log-likelihood & $-11.24 * * *$ \\
Psuedo-R ${ }^{2}$ & 202.55 & .00 \\
N & .29 & \\
\hline
\end{tabular}

$* p<.05 ; * * p<.01 ; * * * p<.001$. 
The second model included students' perceptions and experiences of racial discrimination during college and explained 28 percent of the variance in students with high levels of racial self-consciousness. Students who experienced more racial discrimination during college were more likely to have high levels of racial selfconsciousness. The third model included students' perceptions of their institution's commitment to racial diversity and explained three percent of variance in students with high levels of racial self-consciousness. However, this campus climate measure did not significantly predict whether students had high levels of racial self-consciousness at the end of college or not. The fourth model included students' perceptions of racial separation on campus and explained nine percent of variance in students with high levels of racial self-consciousness. Students who perceived more racial separation on campus were more likely to have high levels of racial self-consciousness. The fifth model included students' perceptions of black student visibility on campus and explained four percent of variance in students with high levels of racial self-consciousness. Students who perceived black students as more visible on campus were less likely to have high levels of racial self-consciousness at the end of college. In the sixth and final model that included all four campus climate measures, this model explained 29 percent of variance in students with high levels of racial self-consciousness. Only two campus climate measures were significant. Students who experienced more racial discrimination during college were more likely to have high levels of racial self-consciousness at the end of college as were students who perceived more racial separation on campus. Across all six models, none of the background characteristics were significant. 
These findings suggest that the campus climate is the driving force behind black students' levels of racial self-consciousness as they graduate college and enter the workforce. These findings raise important questions about black students' experiences during college. In the next chapter, I distill what these findings mean for conversations about black students' experience in college, particularly at historically white colleges and universities, and what efforts could be made to assist students navigate these campuses. 


\section{CHAPTER 6: CONCLUSION AND IMPLICATIONS}

At the start of the current study, I hypothesized that four campus climate processes would greatly influence black college students' racial self-consciousness. Particularly, I predicted that higher levels of experienced racial discrimination would increase black students' racial self-consciousness levels; lower levels of perceived institutional commitment to racial diversity would increase black students' racial selfconsciousness levels; higher levels of perceived racial separation on campus would increase black students' racial self-consciousness levels; and higher levels of perceived black student visibility will decrease black students' racial self-consciousness levels. Ultimately, several campus climate factors triggered black college students' racial selfconsciousness, such as discrimination, racial separation, and black student visibility. In some cases, background characteristics, like skin color and region, influenced student racial self-consciousness. In this final chapter I discuss the results from the current study and how they support or contradict previous research. I conclude with implications gained from this thesis and introduce practices for future researchers and possible campus programs for administrators to improve campus climate for black college students.

\section{Looking Back at Previous Research}

In support of previous research, students from more segregated high schools also had higher levels of racial self-consciousness levels for black students. Previous studies show that students from predominantly white high schools may not perceive as much 
racism on campus in comparison to students from racially mixed or predominantly nonwhite high schools because they may have been better prepared to navigate racially hostile environments. According to this research, students from predominantly white high schools would be better equipped to navigate predominantly white spaces like college campuses (Johnson, Wasserman, Yildirim, \& Yonai, 2014). In the case of black college students, racial segregation in high schools influences their racial self-consciousness as those with high levels of racial self-consciousness frequently entered these predominately white spaces from high schools that were more racially segregated prior to college.

Some preceding studies discuss black student visibility within the scope of acceptance of black culture. Scholars have found that higher education administrators' acceptance of African American culture impacts African American students' academic performance (Lett \& Wright, 2003). In this case, administrators' acceptance of black culture on college campuses could be reflective of black student visibility. Relatedly, the current thesis shows that college type (i.e. private research universities and liberal arts colleges), an institutional characteristic, predicts black student visibility in some models. While previous research insists that administrative acceptance of African American culture is beneficial to black students' academic performance, this is not an efficiently operationalized phenomenon. One may ask, "What does administrative acceptance of African American culture look like?" Thus, researchers may observe more tangible factors that influence black students' academic, professional, and personal lives on campus such as how the type of college can cultivate more acceptance, and thus, more perceptions of visibility. The current study shows that college type, namely liberal arts colleges and private research universities, is a determinant of students' perceptions of 
black student visibility. Looking at the larger picture, black student visibility is a significant predictor for black student racial self-consciousness, which is a major aspect of campus climate. Cultivating a sense of presence on college campuses may be a way to assist black students with navigating the racial contours of their campuses.

Another similarity between the current and previous studies is the subtle differences of college experiences in relation to students' skin color. Past literature tells us that people with darker skin complexions experience more discrimination (Hunter, 2015; Monk, 2014; Monk, 2015; Okonofua \& Eberhardt, 2015). Similarly, and as hypothesized, there was a significant connection between students' skin color and their experiences of racial discrimination in college. That is, black students with darker skin complexions experienced more discrimination during college. My analyses show that although most of the black college students in the study were not reported to have darker skin complexions, respondents with darker complexions were discriminated against more, and when consider student perceptions of their institutions' commitment to racial diversity and racial separation on campus these students were more likely to be more racially self-conscious. This qualifies as a form of colorism on college campuses, which should be expounded upon in future studies about black college students, as well as other research pertaining to discrimination. Importantly, although skin color is a background characteristic and is not a direct issue in discussions of the campus climate, it is reflective of racism occurring on college and university campuses. Black students with darker skin complexions do not dictate their skin tone; however, after centuries of racism, darker skin became and continues to be a strong physiological symbol of "blackness", or “Africanness," which opposes strides toward white dominance (Karenga, 2010). As a 
result, racism and colorism intertwine and coexist throughout the nation, even on US college campuses.

A few results from the current study contrast with previous research as well. While it may be an important factor, my study shows that closeness to other black people does not trigger black students' racial self-consciousness. This differs from previous research on the topic that found black students' academic performance improves when they identify with African American culture and ethnic identity decreases black students' race-based rejection sensitivity levels (Brannon \& Taylor, 2015; Koehler \& Skovoretz, 2010; Mendoza-Denton \& Page-Gould, 2008; Telesford et al., 2013). However, black students' closeness to other blacks is not a determinant of racial self-consciousness or their perceptions of the campus climate. This is a different narrative than what may be portrayed on college campuses. Many express that as students fellowship, particularly in non-conservative safe spaces like black cultural centers, they share racist experiences emanating from their campus climate (Caplan, 2017; Newport \& Busteed, 2017; Rampell, 2017). This idea implies that co-rumination with peers may influence how black students perceive their racialized experiences. Yet, black college students' relationships with other black people do not impact how they perceive their campus climate or their racial self-consciousness.

Additionally, my findings about black students' perceptions of institutional commitment to racial diversity oppose findings in previous literature. In past studies, low levels of commitment to diversity led to increased racial separation and discrimination on campuses (Piper, Esssenberg, \& Matchett, 2013; Karkouti, 2016). The literature also demonstrates that academic performance worsens with less racial diversity (Harper \& 
Yeong, 2013). Yet, the current analyses show that institutional commitments to racial diversity did not trigger black students' racial self-consciousness levels, or racial selfconsciousness at all. This is an interesting finding because higher education institutions emphasize the importance of racial diversity, and in somewhat of a bragging manner (Pippert, Essenburg, \& Matchett, 2013). However, this factor did not matter in the ways black students become conscious of their own race. I must note here that black students' perception of institutional commitment to diversity differs from diversity statements and/or rhetoric around the topic. Commitment refers to the degree of dedication institutions have toward racial diversity with implications that actions will be made to diversify campuses, whereas diversity rhetoric requires no action. Strictly speaking, diversity rhetoric can be found on school websites, pamphlets, and other promotional items for institutions, but there are still low numbers of students of color attending these colleges and universities (Pippert et al., 2013). A reason why colleges and universities may place such an emphasis on racial diversity could be because of black students' demands for more students of color to attend their campuses (see thedemands.org). Pressure from students may influence administrators to claim that racial diversity is a priority for improving campus climate. Though on the other hand of this phenomenon, institutional commitments to racial diversity do not elicit black students' racial selfconsciousness which may be because black students have historically seen little change in racial diversity, thus having less trust in college and university commitments to black student demands. 


\section{Limitations}

Similar to all studies, limitations exist with the current project. One limitation of this thesis is that I utilize older data. The sample was collected beginning in the summer and fall 1999 through the spring 2003. Thus, over a decade has elapsed that may influence what conclusions could be drawn from a similar study of black students on the same campuses today. With this in mind, there may be cultural differences between these students, like technological advances and social media which provide access to information and instant gratification among other factors (Čičević, Samčović, \& Nešić, 2016; Lai, \& Hong, 2015). Although students in the sample somewhat differ culturally from today's students, it is plausible to state that the unequal and discriminatory campus climates on a majority of these campuses has not changed since 1999. Black students continue to face racism that directly deals with discrimination, racial separation, and black student visibility, which is reflected in today's student demands (see thedemands.org). So, while the sample in the current student is "dated," it is extremely relevant to black college students' experiences in recent times.

The use of quantitative data is limiting as well. Utilizing the dataset, we are able to learn a plethora about black students' views on campus climate and their racialized experiences, but it is difficult to fully capture holistic perspectives of the challenges they face. In the future, I should consider utilizing a mixed method approach with both quantitative and qualitative data. I could also utilize college quantitative data through surveys, like surveys in the NLSF dataset to collect racial self-consciousness, campus climate, and demographics. They should compile qualitative data through methods such as interviews, focus groups, and even collecting student journals throughout an academic 
term. Ideally, they should ask black college students to journal any occurrences of racial self-consciousness, or any events surrounding race generally. Responses should be open ended. While student journals would be used to gather qualitative data, they would also be interpreted as quantitative data by analyzing them and coding for reoccurring themes. Hopefully student situations not only include campus climate impact on racial selfconsciousness experiences but would also display students' understanding and attitudes about the phenomenon.

My inclusion of students who graduated from the same institutions they entered in is another limitation. The original number of black students in the NLSF sample was 1,051 , but only 796 graduated from the institutions they attended starting freshman year. This means that 255 students were unaccounted for in this study. These missing students are significant because they may have increased the average level of racial selfconsciousness in the sample, especially if they dropped-out or transferred to find healthier college environments. In the future, researchers should try and consider how these students would impact average racial self-consciousness levels and degrees of campus climate.

Lastly, gender was not statistically significant across all models (except in Table 2). In other words, there was no difference between black women's and men's perceptions of their college campuses, and how these perceptions influenced their racial self-consciousness. This finding differs from the narrative that black women and men face dissimilar gender-based issues at US colleges and universities (Brooms, 2017; Perkins, 2015; Smith et al., 2007; Smith, Hung, \& Franklin, 2011; Szymanski \& Lewis, 2016). Findings in the current study suggest that black women and men face the same 
type of racism, which is problematic because it minimizes the complexity of racism and excludes gendered racism. On the other hand, there are gendered differences in the ways in which men and women experience racism on campuses (Brooms, 2017; Perkins, 2015; Smith et al., 2007; Smith et al., 2011; Szymanski \& Lewis, 2016). To study these gender differences, future research examining the impact of campus climates on black college students' racial self-consciousness could create separate models based on gender to examine how campus climate triggers black women and men college students based on their gender.

\section{Implications}

Results from the current study suggest black college students' background characteristics rarely influence their experiences or perceptions of the campus climate. Rather than focusing on how a student's background may influence their experiences oncampus, researchers and administrators should focus on how the campus climate reflects racism in the campus community, not simply outside of it (Primm, 2018). This returns us to the detrimental idea that something must be inherently "wrong" with the families and communities black students come from prior to college. However, racism is a problem more complex than focusing on an individual's background. Additionally, given racism is a systemic issue in society, focusing only on the overt bigots that may discriminate against black students on campus provides a thin façade of larger issues. These individual-level and interpersonal aspects of racism are used as a scapegoat for seriously considering systematic oppression, especially on college campuses. Often people view white students as the culprits perpetuating racism through their use of racially derogatory slurs and/or hate crimes. However, the racism on college campuses take on several overt 
and covert forms including microaggressions and the insistence for colorblindness both in interpersonal interactions and through policies (Bonilla-Silva, 2017; Smith et al., 2007; Solórzano, et al., 2000; Sue, et al., 2007). In the future, researchers should continue to observe multiple aspects of racism including structural inequalities, microaggressions, and colorblindness by creating additional measures for these phenomena. Additionally, administrators should work to improve the campus climate for black students by holding the campus community accountable for racist actions. Higher education administrations should re-evaluate their institutions' histories of racism, and how they have created environments of inequality for students of color. Moreover, scholars and campus leaders should not attribute racism to bigotry alone but also consider the significance systematic racism has on black college students and campus climates.

Yet, history shows that institutional leaders have betrayed black students, and may not execute plans to eliminate racism at colleges and universities to intentionally and unintentionally incite white dominance (Dancey et al., 2018; Rojas, 2010; Wilder, 2013). Since administrations have not dismantled racism at their institutions, it is plausible that they may not dismantle it in recent times. Therefore, if administrators are not going to change campus climates, they should at least provide tools, such as mental health services, for black students to navigate the racially hostile environment. Not only does dealing with racism in school lead to increased levels of racial self-consciousness, but it could have larger impacts on black students such as racial battle fatigue, which is a variety of psychosomatic symptoms people of color experience while coping with constant racism (Blackmon, 2016; Smith, et al., 2007; Swim, Fitzgerald, \& Bylsma, 2003). Black college students struggling with racial battle fatigue may show symptoms of 
depression, weight gain or loss, loss of concentration, impulsiveness, increases levels of cortisol or stress, and other psychological or physiological issues. Another previously discussed phenomenon black students may show when facing racism on campuses is race-based rejection sensitivity, which could affect black students' academic performance and self-esteem (Mendoza-Denton, et al., 2010; Mendoza-Denton, et al., 2008). While I have mentioned racial battle fatigue and race-based rejection sensitivity as processes black college students experience as symptomatic of discriminatory environments, there are several other coping strategies black students practice, both positive and negative. Fortunately, some black students understand that they undergo psychological struggles because of managing racism and have called for better mental health resources in recent student demands (see thedemands.org).

One more takeaway from this thesis is that black student experiences can be used as valid tools to improve campus climate. In the current era of political and racial hostility, higher education institutions are portraying themselves as sanctuaries for people of color. However, different from colleges and universities' intentions of being safe spaces, the campus climate triggers racial self-consciousness for black students in forms of discrimination, racial separation, and black student visibility. Like stated before, I suggest that researchers find alternative ways to measure the black student experience on campus. While some measures exist through quantitative work (e.g. racial selfconsciousness, perceived discrimination, institutional commitments to racial diversity, racial separation, and black student visibility), we must first ask if policymakers and administrators would seriously acknowledge these quantitative reports and take accountability for racism reflected in the data. A more important, and often underutilized, 
method of measuring racially hostile campus climate is analyzing black student experiences via demonstrations on campus and student demands, after first considering black student experiences as legitimate reflections of the campus environment. When we hear stories like Maya's (the character introduced in the introductory chapter), we must apply that information and utilize it to validate black students' experiences in academia. Ideally, Maya would share her experience with a trusted faculty or staff mentor, who would then share her narrative with campus leadership striving toward racial improvement. Ultimately, campus leaders and administrators should observe black students' perceptions regarding campus climate and its impact on their everyday lives as methods to truly promote colleges and universities as spaces for social and professional development.

\section{Looking to the Future}

I would like to conclude my thesis with some additional strategies administrators could implement to improve college campuses for black college students that directly target racial discrimination, racial separation, and black student visibility. These are general suggestions, so they may not be applicable to all campuses and may not be solutions of racial self-consciousness for other students of color. The following suggestions emphasize both individual and institutional changes that could happen at US colleges and universities in order to address racially hostile campus climates. Because racial self-consciousness was rarely affected by black college students' perceptions of institutional commitment to racial diversity, I have excluded racial diversity on college campuses as a solution to the "racism" problem from the discussion. The following are strategies targeted toward racial discrimination, racial separation, and black student 
visibility that could better signal to students that their administration is seriously committed to racial diversity and equity on campus.

The first strategy I suggest, and is demanded by many students and faculty and staff, is better cultural competency training for all members of the campus community. Essentially, this would introduce black students' leaders and peers to historical context and possibly prevent intentional and unintentional racial discrimination. Within cultural competency training, students, faculty, and staff should learn the differing components of racism such as colorblindness, microaggressions, stereotyping, discrimination, and systematic racism and how to prevent them from occurring or how to intervene if they witness such acts.

Another important strategy to eradicate racism on college and university campuses is for institutions to adopt stricter anti-discrimination policies. Oftentimes, black college students are triggered by racial hate crimes. Take for example the Lambda Chi Alpha fraternity at California Polytechnic State University, San Luis Obispo, who dressed as black male stereotypes at a party (Eltagouri, 2018). While some of the fraternity members dressed as gangster stereotypes, others went as far as to wear blackface. The fraternity is currently on interim suspension, but the institution's administrators have not disciplined individuals. The issue here is that students can continue at their institutions without being subject to consequences because the fraternity is liable, not individuals. Furthermore, when individuals are disciplined, they are not fully brought to justice. An example of this occurred in 2013. Three white students at San Jose State University who harassed a black peer several times, which included putting a Ushaped bike lock around his neck and calling him, "three-fifths a person," (Murdock, 
2016). While the students were caught, they were not convicted of hate crimes. A more recent example is Brianna Brochu, a white student who contaminated her black roommate's belongings with molded food products and bodily fluids, to the point that the roommate became physically ill (Edwards, 2018). Brochu did appear in court but was not convicted of hate crimes either. In both cases, and a plethora more throughout history and across the country, higher education's support of violence against black people are forms of anti-blackness. Sadly, US colleges and universities deem direct acts of anti-blackness as negligible and negate or gloss over the history of violence against black people on campus and resulting suffering (Dancey et al., 2018).

Higher education institutions where incidents like these occur should hold more accountability in serving justice. While the students may be expelled from these schools, these higher education institutions should be obligated to take a stance against perpetrators. Dancey et al. (2018) gives an ideal protocol for stricter policies against racist occurrences on college campuses stating, "If the campus is progressive, the particular incident... will be swiftly addressed and repudiated. Punishment will be summarily delivered to the individuals clearly responsible, and the campus will disavow the incident" (p. 189). Perhaps black college students' peers would reconsider racist actions if victims were guaranteed the institution's support.

The last strategy I will mention for higher education institutions is to adopt wellness techniques for black students. If it is impossible to uproot racism from US colleges and universities, there must be healthy methods for black college students to productively cope with racial discrimination, separation, and low black student visibility. In addition to mental health services, schools should invest in programs for black 
students' physical and academic wellness as methods of enduring through intolerant campus climates. These programs would only be for black college students. For instance, programs for physical health may include yoga sessions, run clubs, intermural sports, or weight training. Academic programs may include opportunities for current black students to mentor incoming students based on expected majors, black-only study groups, and more spaces for students to study more comfortably (e.g. lounges, libraries, etc.).

Although these strategies may better black students' racial self-consciousness or other psychological processes like rejection sensitivity race-based, they will be unsuccessful if higher education leaders do not strive to make these practices a part of everyday campus climate for black students. People in power at colleges and universities, such as administrators, trustees, and faculty should fully support and participate in the programs mentioned above, which may improve black college students' perceptions of black student visibility. Furthermore, these programs must be implemented repeatedly. To finish, these programs must be carefully planned and strategized, and should be flexible to accommodate the heterogeneity of black college students. With well thoughtout programming and appropriate resources, campus climate may greatly improve black college students' racial self-consciousness and their wellness holistically. 


\section{REFERENCES}

Allport, G. W. (1954). The Nature of Prejudice. Reading, MA: Addison-Wesley.

Anderson, J. (1988). The Education of Blacks in the South, 1860-1935. The University of Chapel Hill, NC: North Carolina Press.

Blackmon, S. M. (2016). Linking racial-ethnic socialization to culture and race-specific coping among African American college students. Journal of Black Psychology, 42(6), 549-576. doi:

http://dx.doi.org.echo.louisville.edu/10.1177/0095798415617865.

Bonilla-Silva, E. (2015). The structure of racism in color-blind, "post-racial" America. American Behavioral Scientist, 59(11), 1358-1376. doi:

$10.1177 / 0002764215586826$.

Bonilla-Silva, E. (2017a). Racism Without Racists: Color-Blind Racism and the Persistence of Racial Inequality in America ( $5^{\text {th }}$ ed.). Lanham, MD: Rowman \& Littlefield Publishers.

Bonilla-Silva, E. (2017b). What we were, what we are, and what we should be: The racial problem of American sociology. Social Problems, 64(2), 179-187. doi:

10.1093/socpro/spx006

Bowman, P., Muhammad, R., \& Ifatunji, M. (2004). Skin tone, class, and racial attitudes among African Americans. In Skin Deep: How Race and Complexion Matter in the "Color-Blind" Era. Chicago: University of Illinois Press. 
Boyraz, G., Horne, S. G., Owens, A. C., \& Armstrong, A. P. (2013). Academic achievement and college persistence of African American students with trauma exposure. Journal of Counseling Psychology, 60(4), 582-592. doi:

$10.1037 / \mathrm{a} 0033672$

Brannon, T. N., Markus, H. R., \& Taylor, V. J. (2015). “Two souls, two thoughts,” two self-schemas: Double consciousness can have positive academic consequences for African Americans. Journal of Personality and Social Psychology, 108(4), 586609. doi: http://dx.doi.org/10.1037/a0038992

Brooms, D. R. (2017). Being Black, Being Male on Campus: Understanding and Confronting Black Male Collegiate Experiences. Albany, NY: Suny Press.

Byrd, W. C. (2017). Poison in the Ivy: Race Relations and the Reproduction of Inequality on Elite College Campuses. New Brunswick, NJ: Rutgers University Press.

Caplan, J. (2017, October 24). Trump Jr. scolds universities during UNT speech, a fundraiser for scholarships. [blog]. Retrieved from http://www.startelegram.com/news/politics-government/national-politics/article180651831.html

Carmichael, S., \& Hamilton, C. V. (1967). Black Power: The Politics of Liberation. New York: Random House.

Čičević, S., Samčović, A., \& Nešić, M. (2016) Exploring college students’ generational differences in Facebook usage. Computers in Human Behavior, 56, 83-92. doi: 10.1016/j.chb.2015.11.034 
Clark, K. B., \& Clark, M. K. (1939). The development of consciousness of self and the emergence of racial identification in negro preschool children. The Journal of Social Psychology, S.P.S.S.I. Bulletin, 10, 591-599

Dancey II, T. E., Edwards, K. T., \& Davis, J. E. (2018). Historically white universities and plantation politics: Anti-blackness and higher education in the black lives matter era. Urban Education, 53(2), 76-195. doi: 10.1177/004285918754328

Downey, G., \& Feldman, S. I. (1996). Sensitivity to status-based rejection: Implications for African American students' college experience. Journal of Personality and Social Psychology, 83, 896-918. doi: http://dx.doi.org/10.1037/0022-3514.83.4.8

Edwards, B. (2018, March 12). College student who smeared bodily fluids on black roommate's belongings receives special probation to avoid criminal record. How not shocking. [blog]. Retrieved from https://www.theroot.com/connecticutstudent-who-smeared-bodily-fluids-on-black-1823704388.

Eltagouri, M. (2018, April 10). Fraternity brothers posed in blackface and gangster costumes, this college's latest racist dust-up. [blog]. Retrieved from https://www.washingtonpost.com/news/grade-point/wp/2018/04/10/fraternitybrothers-posed-in-blackface-and-gangster-costumes-this-colleges-latest-racistdust-up/?utm term=.f1f38d3e6eac.

Gambrill, E. D. \& Richey, C. A. (1975). An assertion inventory for us in assessment and research. Behavior Therapy, 6(4), 550-561. doi: https://doi.org/10.1016/S0005$\underline{7894(75) 80013-X}$ 
Greenwald, A. G., \& Banaji, M. R. (1995). Implicit social cognition: Attitudes, selfesteem, and stereotypes. Psychological Review, 102(1), 4-27. doi:10.1037/0033295X.102.1.4

Griggs, B. (2015, November 10). Do U.S. colleges have a race problem? [blog]. Retrieved from https:/www.cnn.com/2015/11/10/us/racism-college-campusesprotests-missouri/index.html.

Harburg, E. et al. (1978). Skin color, ethnicity, and blood pressure I: Detroit blacks. American Journal of Public Health, 68(12), 1177-1183.

Harper, C. E., \& Yeung, F. (2013). Perceptions of institutional commitment to diversity as a predictor of college students' openness to diverse perspectives. The Review of Higher Education, 37(1), 25-44. doi: 10.1353/rhe.2013.0065

Henson, J. M., Derlega, V. J., \& Pearson, M. R. (2013). African American student's responses to racial discrimination: How race-based rejection sensitivity and social constraint are related to psychological reactions. Journal of Social and Clinical Psychology, 32, 504- 529.

Hunter, M. (2015). Colorism in the classroom: How skin tone stratifies African American and Latino/a Students. Theory Into Practice, 55(1), 54-61. doi: http://dx.doi.org/10.1080/00405841.2016.1119019.

Iziarry, Y. (2015). Selling students short: Racial differences in teachers' evaluations of high, average, and low performing students. Social Science Research, 52, 522538. doi: http://dx.doi.org/10.1016/j.ssresearch.2015.04.002 
Jackson, R., Sweeney, K., \& Welcher, A. (2014). It just happens: Colorblind ideology and undergraduate explanations of racial interaction on campus. Education, Citizenship and Social Justice, 9(3), 191-208.

Jackson, S. (2016, April 25). 5 things black students say will end racism on college campuses. [blog]. Retrieved from https://splinternews.com/5-things-black$\underline{\text { students-say-will-end-racism-on-college-1793856430. }}$.

Johnson-Ahorlu, R. (2013). "Our biggest challenge is stereotypes": Understanding stereotype threat and the academic experiences of African American undergraduates. Journal of Negro Education, 82(4), 382-392.

Johnson, D. R., Wasserman, T. H., Yildirim, N., \& Yonai, B. A. (2014). Examining the effects of stress and campus climate on the persistence of students of color and white students: An application of Bean and Eaton's psychological model of retention. Research in Higher Education, 55(1), 75-100.

Johnson, J. J., Farrell, W. J., \& Stoloff, J. (1998). The declining social and economic fortunes of African American males: A critical assessment of four perspectives. Review of Black Political Economy, 25(4), 17-40.

Karenga, M. (2010). Introduction to Black Studies. Los Angeles, California: University of Sanokore Press.

Karkouti, I. M. (2016). Black students' educational experiences in predominantly white universities: A review of the related literature. College Student Journal, 50(1), 5970. 
Keith, V. M., \& Herring, C. (1991). Skin tone and stratification in the black community. The American Journal of Sociology, 97(3), 760-778.

Koehler, G., \& Skvoretz, J. (2010). Residential segregation in university housing: The mathematics of preferences. Social Science Research, 39(1), 14-24. doi: 10.1016/j.ssresearch.2009.05.004.

Kozol, J. (1992). Savage Inequalities: Children in America's Schools. New York, NY: Harper Perrinial.

Krieger, N., Sidney, S., \& Coakley, E. (1998). Racial discrimination and skin color in the CARDIA study: Implications for public health research. Coronary artery risk development in young adults. American Journal of Public Health, 88(9), 13081313.

Lai, K-W., \& Hong, K-S. (2015). Technology use and learning characteristics of students in higher education: Do generational differences exist? British Journal of Educational Technology, 46(4), 725-738. doi: 10.1111/bjet.12161

Lett, D. F., \& Wright, J. V. (2003). Psychological barriers associated with matriculation of African American students in predominantly white institutions. Journal of Instructional Psychology, 30(3), 189.

Lewis-McCoy, R. L. (2014). Inequality in the Promised Land: Race, Resources, and Suburban Schooling. Stanford, CA: Stanford University Press. 
Massey, D. S., Charles, C. Z., Lundy, G. F., \& Fischer, M. J. (2003). The Source of the River: The Social Origins of Freshmen at America's Selective Colleges and Universities. Princeton, N.J.: Princeton University Press.

McNamara, J. R. (1984). The assertion inventory: Its relationship to social desirability and sensitivity to rejection. Psychological Reports, 55(3), 719-724. http://dx.doi.org.echo.louisville.edu/10.2466/pr0.1984.55.3.719

Mehrabian, A. (1970a). The development and validation of measure of affiliative tendency and sensitivity to rejection. Education and Psychological Measurement, $30(2), 417-428$.

Mehrabian, A. (1970b). Some determinants of affiliation and conformity. Psychological Reports, 27(1), 19-29. oi: http://dx.doi.org.echo.louisville.edu/10.2466/pr0.1970.27.1.19

Mehrabian A., \& Ksionzky, S. (1972). Some determiners of social interaction. Sociomety, 35(4), 588-609. doi: http://dx.doi.org.echo.louisville.edu/10.2307/2786535

Mendoza-Denton, R., Downey, G., Purdie, V., Davis, A., \& Piertzak, J. (2002). Sensitivity to status-based rejection: Implication for African American students' college experience. Journal of Personality and Social Psychology, 83, 896-918. doi: http://dx.doi.org/10.1037/0022-3514.83.4.896

Mendoza-Denton, R., Goldman-Flythe, M., Pietrzak, J., Downey, G., \& Aceves, M. J. (2010). Group-value ambiguity: Understanding the effects of academic feedback 
on minority students' self-esteem. Social Psychological and Personality Science, 1, 127-135. doi: http://dx.doi.org/10.1037/0022-3514.83.4.896

Mendoza-Denton R., \& Page-Gould, E. (2008). Can cross-group friendships influence minority students' well-being at historically White universities? Psychological Science, 19, 933-939. doi: http://dx.doi.org/10.1111/j.1467-9280.2008.02179.x

Mendoza- Denton, R., Pietrzak, J., \& Downey, G. (2008). Distinguishing institutional identification from academic goal pursuit: Interactive effects of ethnic identification and race-based rejection sensitivity. Journal of Personality and Social Psychology, 95, 338- 351. doi: http://dx.doi.org/10.1037/0022-

\section{$\underline{3514.95 .2 .338}$}

Monk, E. P. (2014). Skin tone stratification among black Americans, 2001-2003. Social Forces, 92(4), 1313-1337.

Monk, E. P. (2015). The cost of color: Skin color, discrimination, and health among African Americans. American Journal of Sociology, 121(2), 396-444.

Murdock, S. (2016, February 2). White college students who put bike lock around black student's neck avoid hate crime convictions. [blog]. Retrieved from https://www.huffingtonpost.com/entry/san-jose-state-not-ruled-hatecrime us 56ccb48de4b041136f188b0e.

National Longitudinal Study of Freshmen (2008) [Data file]. Retrieved from http://nlsf.princeton.edu/data.htm 
Newport, F., \& Busteed, B. (2017, August 16). Why are republicans down on higher ed? [blog]. Retrieved from http://news.gallup.com/poll/216278/why-republicansdownhigher.aspx?g_source=POLITICAL_PARTIES\&g_medium=topic\&g campaign= $\underline{\text { tiles }}$

Okonofua, J. A. \& Eberhardt, J. L. (2015). Two strikes: Race and the disciplining of young students. Psychological Science, 26(5), 617-624. doi:

$10.1177 / 0956797615570365$

Page-Gould, E., Mendoza-Denton, R., \& Mendes, W. B. (2014). Stress and coping in interracial contexts: The influence of race-based rejection sensitivity and crossgroup friendship in daily experiences of health. Journal of Social Issues, 70, 256278. doi: http://dx.doi.org/10.1111/josi.12059

Perkins, L. M. (2015). "Bound to them by sorrow": African American women, higher education, and collective advancement. Journal of African American History, $100(4), 721-747$.

Pippert, T. D., Essenburg, L. J., \& Matchett, E. J. (2013). We’ve got minorities, yes we do: Visual representations of racial and ethnic diversity in college recruitment materials. Journal of Marketing for Higher Education, 23(2), 258-282. doi: $10.1080 / 08841241.2013 .867920$

Primm, A. B. (2018, April 2). College students of color: Confronting the complexities of diversity, culture, and mental health. [blog]. Retrieved from 
https://www.higheredtoday.org/2018/04/02/college-students-color-confrontingcomplexities-diversity-culture-mental-health/

Rojas, F. (2010). From Black Power to Black Studies: How a Radical Social Movement Became an Academic Discipline. Baltimore, MD: John Hopkins University Press.

Rampell, C. (2017, December 28). Why do so many republicans hate college? [blog]. Retrieved from https://www.washingtonpost.com/opinions/why-do-so-manyrepublicans-hate-college/2017/12/28/db55f5f6-ec16-11e7-b69891d4e35920a3_story.html?noredirect=on\&utm term $=.1 \mathrm{~b} 726 \mathrm{ce} 57 \mathrm{~d} 2 \mathrm{f}$

Smith, C. E., \& Hopkins, R. (2004). Mitigating the impact of stereotypes on academic performance: The effects of cultural identity and attributions for success among African American college students. Western Journal of Black Studies, 28(1), 312321.

Smith, W. A., Hung, M., \& Franklin, J. D. (2011). Racial battle fatigue and the miseducation of Black men: Racial microaggressions, societal problems, and environmental stress. The Journal of Negro Education, 80(1), 63-82.

Smith, W. A., Allen, W. R., \& Danley, L. L. (2007). “Assume the position... you fit the description": Psychosocial experiences and racial battle fatigue among African American male college students. American Behavioral Scientists, 51(4), 551-578. doi: http://dx.doi.org.echo.louisville.edu/10.1177/0002764207307742.

Solórzano, D. G., Ceja, M., \& Yosso, T. J. (2000). Critical race theory, racial microaggressions, and campus racial climate: The experiences of African American college students. The Journal of Negro Education, 69(1/2), 60-73 
Steele, C. M. (1997). A threat in the air: How stereotypes shape intellectual identity and performance. American Psychologist, 52(6), 613-629. doi: http://dx.doi.org/10.1037/0003-066X.52.6.613

"Strategies for reducing racial and ethnic prejudice: Essential principles." Retrieved from https://www.tolerance.org/professional-development/strategies-for-reducingracial-and-ethnic-prejudice-essential-principles on April 15, 2018.

Sue, D. W., Capoduilupo, C. M., Torino, G. C., Bucceri, J. M., Holder, A. B., Nadal, K. L., \& Esquilin, M. (2007). Racial microaggressions in everyday life: Implications for clinical practice. American Psychologist, 62(4), 271-286.

Swim, J. K., Hyers, L. L., Cohen, L. L., Fitzgerald, D. C., \& Bylsma, W. H. (2003). African American college students' experiences with everyday racism: Characteristics of and responses to these incidents. Journal of Black Psychology, 29(1). 38-67. doi:

http://dx.doi.org.echo.louisville.edu/10.1177/0095798402239228.

Szymanski, D. M. \& Lewis, J. A. (2016). Gendered racism, coping, identity centrality, and African American college women's psychological distress. Psychology of Women Quarterly, 40(2), 229-243.

Telesford, J., Mendoza-Denton, R., \& Worrell, F. C. (2013). Clusters of CRIS scores and psychological adjustment. Cultural Diversity and Ethnic Minority Psychology, 19(1), 86-91. doi: 10.1037/a0031254

United States Census Bureau (2015). Retrieved from https://www.census.gov/quickfacts/table/PST045216/00. 
United States Census Bureau (2017). Retrieved from

https://www.census.gov/data/tables/2016/demo/education-attainment/cpsdetailed-tables.html.

WeTheProtesters. Student demands. Retrieved from http://www.thedemands.org/

Wilder, C. S. (2013). Ebony and Ivy: Race, Slavery, and the Troubled History of America's Universities. New York, NY: Bloomsbury Press.

Wu, I. H., Lyons, B., \& Leong, F. T. L. (2015). How racial/ethnic bullying affects rejection sensitivity: The role of social dominance orientation. Diversity and Ethnic Minority Psychology, 21, 156-161. doi:

http://dx.doi.org/10.1037/a0037930

Zuberi, T. \& Bonilla-Silva, E. (2008). White Logic, White Methods: Racism and Methodology. Lanham, MD: Rowman \& Littlefield Publishers. 


\section{CURRICULUM VITAE}

\section{CONTACT INFORMATION}

Department of Pan-African

445 Strickler

University of

Louisville, KY 40292

leanna.luney@gmail.com
Studies Phone: 502-852-5985

Hall Fax: 502-852-5954

Louisville_Email: 1tlune01@louisville.edu_or

\section{RESEARCH INTERESTS}

African American student perceptions, stereotypes, expectations of rejection, structural inequality.

\section{EDUCATION}

2018 (Expected)

2016

EXPERIENCE

2016 - Present

of

$2016-2017$

Research,

2015

Women
M.A. in Pan-African Studies, University of Louisville Thesis: "'Triggers': Systematic and Social Cues for African American College Student Racial Self-Consciousness and Rejection Sensitivity, Race Based”

B.A. in Psychology, Berea College

B.A. in African \& African American Studies, Berea College

Graduate Assistant, Department of Pan-African Studies, University

Louisville.

Graduate Assistant, Anne Braden Institute for Social Justice

University of Louisville.

Summer Intern, Mary McLeod Bethune Council House for Negro

National Historic Site, National Park Service, Washington, D.C.

\section{PUBLICATIONS}

Luney, L. (2016). Working for the Canaan land: The relationship between work ethic and happiness in African and Caucasian Americans. The Griot: The Journal of African American Studies, 35(2), 188-202. 


\section{WORKS IN PROGRESS}

Byrd, W. C., Luney, L. T., Marie, J., Sanders, K. N. Demanding attention: An exploration of the institutional characteristics of student demands, 2015-2016. Research in Higher Education. (Under Review)

\section{SCHOLARSHIPS AND AWARDS}

Full Tuition Scholarship, Berea College, 2012-2016.

Benjamin A. Gilman International Scholarship, 2014.

\section{PRESENTATIONS, WORKSHOPS, AND PANELS}

2017 "The Problem of the Color Line Continues: An Exploration and Conversation about the Impact of the Racial Divide in the $21^{\text {st }}$ Century", Association for the Study of African American Life and History (ASALH), September, Cincinnati, OH.

2017 "Let's Talk About It: Black Mental Health", Black Lives Matter

Louisville,

August, Louisville, KY.

2017 "'Collective Courage' Graduate Student Discussion," University of

Louisville,

2017 "Intersections of a Movement," at Engage Kentucky Alliance Symposium, University of Louisville, February, Louisville, KY.

2015 "Do Berea College's African American Students have 'Trust Issues'?”,

Berea

College, October, Berea, KY.

FIELD EXPERIENCE AND PROJECTS

2015 "American Black Psychology and Contemporary Issues", Berea College, Berea, KY.

\section{STUDY ABROAD EXPERIENCE}

2017

2014

Caribbean Festivals and Traditions, Trinidad and Tobago, Summer.

African Literature and Music, Ghana, Summer. 